Portland State University

PDXScholar

1976

\title{
The Role of American Diplomacy in the Louisiana Purchase
}

Rebecca Warren

Portland State University

Follow this and additional works at: https://pdxscholar.library.pdx.edu/open_access_etds

Part of the United States History Commons

Let us know how access to this document benefits you.

\section{Recommended Citation}

Warren, Rebecca, "The Role of American Diplomacy in the Louisiana Purchase" (1976). Dissertations and Theses. Paper 2581.

https://doi.org/10.15760/etd.2578

This Thesis is brought to you for free and open access. It has been accepted for inclusion in Dissertations and Theses by an authorized administrator of PDXScholar. Please contact us if we can make this document more accessible: pdxscholar@pdx.edu. 
AN ABSTRACT OF THE THESIS OF Rebecca Warren for the Master of Arts in History presented May 20, 1976.

Title: The Role of American Diplomacy in the Louisiana Purchase.

APPROVED BY MEMBERS OF THE THESIS COMMITTEE:
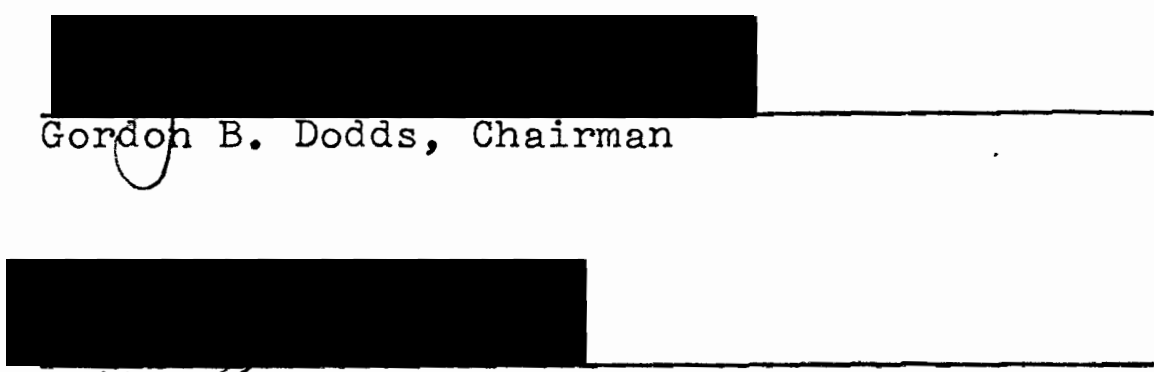

Whitnez Bates

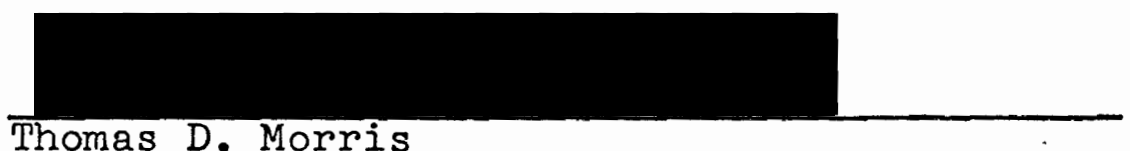

When a powerful and ambitious nation peacefully transfers almost $600,000,000$ acres to a comparatively insignificant nation, the event deserves careful scrutiny and evaluation. The Louisiana Purchase of 1803 was such a transaction. Although events and personalities surrounding the Purchase were complex and numerous, the one factor to be examined here is the role of American diplomacy. The problem is to determine the influence American diplomacy had in securing 
the Louisiana Purchase.

American diplomacy of 1803 originated with President Thornas Jefferson and Secretary of State James Madison. To understand their goals and frustrations, their letters and writings have been examined. The diplomats entrusted with executing Arnerica's foreign policy and negotiating with Spain, England and France were Charles Pinckney, Rufus King, Robert Livingston and James Monroe. Letters and biographies of these diplomats, with the exception of Charles:Pinckney, have also been reviewed. Charles Pinckney's activities are mentioned briefly since his diplomacy was only tangential to the events in France and the United States.

Other sources were: biographies of Jefferson, Monroe and Livingston; histories of Spain, France, the United States and Louisiana; the American State Papers and additional Government publications.

From these sources the role of American diplomacy in the Louisiana Purchase appears creative, assertive and persistent. Jefferson and Madison were careful to preserve peace while promoting American interests. Together Robert Livingston and James Monroe, America's ministers in France, acquired Louisiara. The reasons for the Purchase lie, in part, with American diplomacy and, in part, with Napoleon. Robert Livingston persistently reminded French of îcials of the economic disadyantages of developing. Louisiana and of 
the unlikelihood that Americans would long tolerate the closure of New Orleans. In Washington D. C. Jefferson and Madison used the French charge Pichon to communicate to French Minister Talleyrand this American belligerency. The appointment of James Monroe demonstrated the United States' commitment to resolve those points of contention between France and the U. S.

Meanwhile Napoleon was watching his dreams of a French empire in North America crumble as his disease-ridden army failed to acquire control of santo Domingo. If his army could not conquer Santo Domingo, the hope of a successful French defense of New Orleans, in case of an American attack, dimmed. America's offer to buy New Orleans and the Floridas proved that she possessed money and was committed to resolve the immediate problems of the right of deposit at New Orleans and the right to navigate the Mississippi River. American diplomats offered an alternative which the First Consul initially ignored but eventualiy accepted as his plans for a French empire in North America we destroyed. Napoleon's failure in Louisiana and his renewed interest in fighting England compelled him to accept an alternative which provided him with money for armaments. The First Corsul averted his attention from Louisiana to Europe and the Louisiana Purchase was negotiated. To France the transaction was a means to renew her expansionistic efforts in Europe: to the United States the Purchase was an unexpected 
milestone which offered innumerable agricultural and economic opportunities and provided an additional impetus to America's westward movement. 


\section{THE ROLE OF AMERICAN DIPLOMACY}

IN THE LOUISIANA PURCHASE

by

REBECCA WARREN

A thesis submitted in partial fulfillment of the requirements for the degree of

MASTER OF ARTS

in

HISTORY

PORTLAND STATE UNIVERSITY

1976 
TO THE OFFICE OF GRADUATE STUDIES AND RESEARCH:

The members of the Committee approve the thesis of Rebecca Warren presented May 20, 1976.
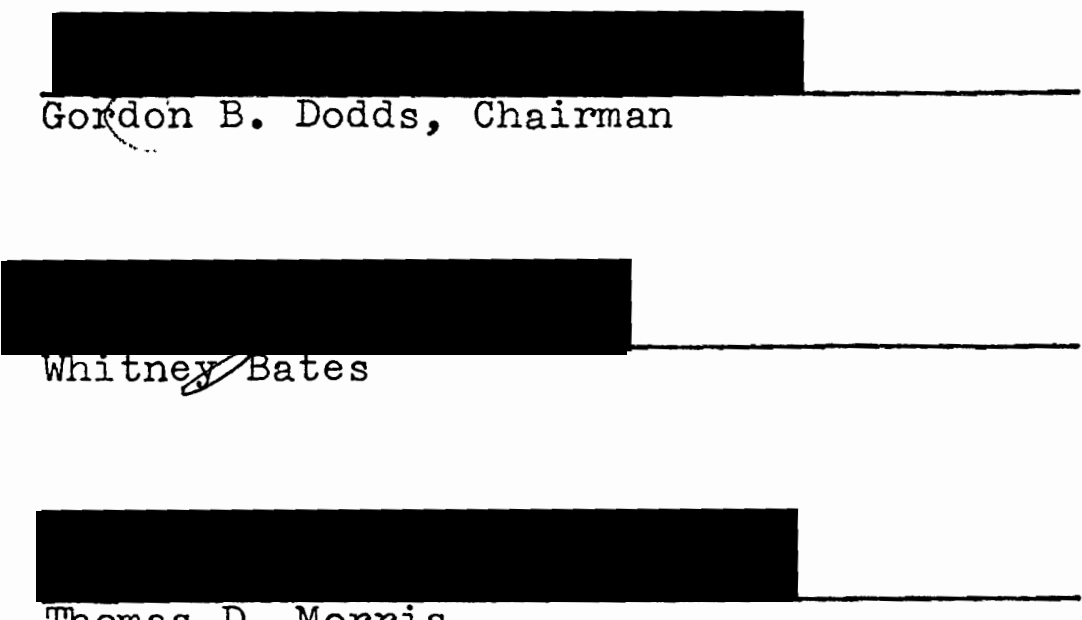

APPROVED:

Thomas D. Morris

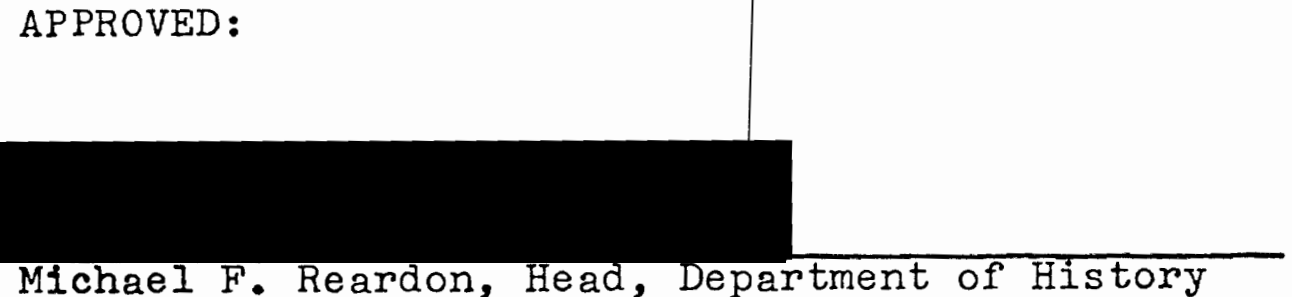

Richłrd B. Halley, Acting Dean of graduate Studies 
TABLE OF CONTENTS

PAGE

CHAPTER

I INTRODUCTION . . . . . . . . . . . . . . I

II AMERICAN FOREIGN POLICY AND THE

LOUISIANA CESSION •. • • • . • • • . 7

III THE AMERICAN DIPLOMATS . . . • • • • . 17

IV PROBLEMS IN PARIS . . . . . . . . . 34

V THE ENERGETIC LIVINGSTON . • . . . . . . 54

VI THE JOINT COMMISSION AND THE

LOUISIANA PURCHASE . . . . . . . . 82

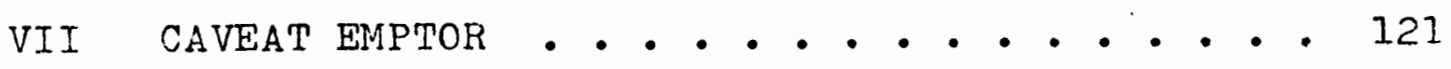

VIII CONCLUSION . . . . . . . . . . . 128

BIBLIOGRAPHY ............. 230 


\section{CHAPTER I}

\section{INTRODUCTION}

On May 2, 1803 France ceded almost six hundred million acres to the United States. The cession formally ended French attempts to establish a western empire and allowed the United States to extend her borders beyond the Mississippi River. French motives remained expensionistic but Napoleon diverted his attention from Louisiana to Europe. This diversion, resulting from the French failure to regain control of Santo Domingo, was opportune for the American diplomat, Robert R. Livingston, who was attempting to purchase New Orleans and the Floridas from Napoleon. Robert Livingston's efforts were only one factor of several which encouraged France to relinquish Louisiana to a relatively insignificant foreign nation. Robert livingston, James Monroe, Thomas Jefferson and James Madison used influence arrogance, persistence and unorthodox suggestions to preserve American interests by winning concessions from France. When the French interest in colonizing North America declined, America's willingness to buy land and her apparent ability to provide money for such purchases encouraged the French. Resumption of war with England required specie and since Americans seemed a likely source, the French engaged the 
Americans in serious negotiations regarding Louisiana. Less than one month after the French offered to sell all of Louisiana, the transaction known as the Louisiana Purchase was officially completed.

The Purchase involved territory which had been discovered by the Spaniards as early as 1519.1 Spanish and French explorers continued to explore the terrain for mercantilistic reasons until the 1660's when the estranged French coureurs des bois, Radisson and Groseilliers, suggested to England's Charles II that the fertile Mississippi Valley be colonized ? $^{2}$ This English interest in colonization was short-lived but the French, fearing these Anglo-expansionistic designs, likewise encouraged the exploration and colonization of the Mississippi Valley. In 1674 Louis Joliet and Father Jacques Marquette traveled 2,750 miles on the Mississippi River and confirmed that the Mississippi Valley was vast and incalculably rich for agriculture and mining. ${ }^{3}$ Eight years later LaSalle explored the River to its mouth and on April 9, 1682 claimed Louisiana for France. Although LaSalle encouraged French officials to establish colonial settlements in Louisiana,

$I_{\text {Marshall Sprague, So Vast, So Beautiful A Land: }}$ Louisiana and the Purchase (Boston: Little, 1974), p. 5.

$$
\begin{aligned}
& \text { Ibid., p. } 22 . \\
& 3_{\text {Ibid. }} \text { p. } 37 .
\end{aligned}
$$


such colonization was not undertaken due to a change of leadership in Quebec which discouraged both exploration and colonization. 4

Apparently the French government changed its mind in 1698 when Pierre Le Moyne, sleur, diberville, was assigned to explore the Mississippi Valley. He recommended that missions be established in the area and tobacco, indigo, rice and wheat beraised. 5 Iberville and his crew built forts and founded towns. In 1704 seventy-five soldiers, five priests from Quebec, two nuns and twenty-three women arrived in Louisiana from France in order to establish a colony. 6

From 1704 to 1762 colonization was unprofitable. There was gradual progress in agricultureand mining but France failed to receive any investment returns--a fact which did not endear Louisiana to France. 7 At the close of the French and Indian War in the Treaty of Fontainebleau of November 3, 1762, the defeated French ceded Louisiana to Spain. 8

${ }^{4}$ Sprague, p. 57 .

${ }^{5}$ Ibid., pp. 88-90:

${ }^{6}$ James Q. Howard, History of the Louisiana Purchase (Chicago: Callaghan \& Company, 1902), p. 23.

7 Binger Hermann, The Louisiana Purchase (Washington D.C.: U. S. Government Printing orfice, I8981, p. I8.

$8_{\text {Howard, p. } 28 .}$ 
While the Spanish governed Louisiana, Americans ventured westward and New Orleans became a most important commercial center. The Mississippi River was an essential highway to western American farmers and the right of deposit at New Orleans was an invaluable economic asset. At the close of the Revolutionary War English concessions extended the boundaries of the United States to the Mississippi River and assured her the right to navigate the River. Spain, believing that the navigation of the Mississippi aas a privilege to be granted only during critical times, advocated that American navigation should be diaallowed. 9

It took twelve years to reach an agreement between Spain and the U. S. regarding the Missigsippi River and $\checkmark$ New Orleans. In the Pinckney Treaty of 1795 Americans acquired the right to navigate the Mississippi and the right of deposit at New Orleans. 10 At: the end of three years, this agreement was to be reviewed and if the Spanish decided that New Orleans should no longer be the deposit place, another site, somewhere on the banks of the Mississippi, was to be selected. 11

From 1795 to 1800 the United States continued to enjoy the rights guaranteed in the Pinckney Treaty. Americans were

${ }^{9}$ Howard, pp. 30-34.

${ }^{10}$ Paul A. Varg, Foreign Policies of the Founding Fathers (East Lansing, Michigan: Michigan State University Press, 1963), p. 150 .

${ }^{11}$ Hermann, p. 24 . 
secure with these rights; economic growth continued and shippers found the arrangement most advantageous as they also avoided the payment of custom duties. ${ }^{12}$ While Americans grew increasingly dependent on the Mississippi River and New Orieans, Spain signed with Fance the secret Treaty of San Ildefonso in October 1800. France acquired Loulsiana while Spain received the Italian province of Tuscany. 13

Americans' sense of security was distiubed by rumors of the cession. The report had to be verified and the American minister in England, Rufus King, was the first to acquire and dispatch official confirmation when he enclosed a copy of the treaty in a letter dated November 20, 1801 to Secretary of State James Madison. 14

Americans. were apprehensive. Spain had been a passive neighbor and it was difficult to predict what France would do under the leadership of the militaristic Napoleon. France and England had concluded their Peace Preliminaries in October 1801 and with war between these two countries drawing to a close, France might divert her attention to North America. 15

12 Merrill D. Peterson, Thomas Jefferson \& the New Nation (New York: Oxford University Press, 1970), p. 746.

13 Sprague, p. 279.

14 Dumas Malone, Jefferson and His Time, vol. 4, Jefferson the President (Boston: Little, Brown \& Company, 1962), p. 248 . $15 \mathrm{~J}$. Steven Watson, The Reign of George III (Oxford: Clarendon Press, 1970), p. 410. 
French General Leclerc's expedition to Santo Domingo in 1801 to quell Toussaint L'Ouverture's rebellion of blacks and to reatablish French control of the island indicated that Napoleon was interested in western affairs. The presence of 30,000 French soldiers close. to the states enhanced the anxieties of a number of American sitizens and leaders. 16 To monitor French activities, the newly-elected President, Thomas Jefferson, and the recently-appointed Secretary of State, James Madison, formulated and condueted an assertive, but cautious, foreign policy, Ale American diplomats in England, Spain and France endeavored to verify rumors and protect American interests.

16 Marshall Smelser, The Democratic Republic: 18011815 (New York; Harper \& Row, 1968), p. 89. 


\section{CHAPTER II}

\section{AMERICAN FOREIGN POLICY AND THE LOUISIANA CESSION}

\section{Thomas Jefferson's participation in politics dated}

back to 1769 when he was a member of the Virginia House of Burgesses. From Virginia, Jefferson ventured to Philadelphia as a delegate to the First and Second Continental Congresses. In 1784 the Congress appointed Jefferson to join Benjamin Franklin and John Adams in France to engage in negotiations for commercial treaties in Europe. ${ }^{1}$ Jefferson left France in 1789 with lans to retire to Monticello but en route home learned that President George Washington had appointed him Secretary of State. When John Adams was elected President in 1796, Jefferson was elected Vice-President and his dissatisfaction with Adam's policies compelled him to campaign actively in the Presidential race of 1800 . A tie resulted between Aaron Burr and Thomas Jefferson and the election was transferred to the House of Representatives. On February 17, 1801 Jefferson was elected President by a margin of one vote. 2 His victory was narrow but this failed to restrain his attempts

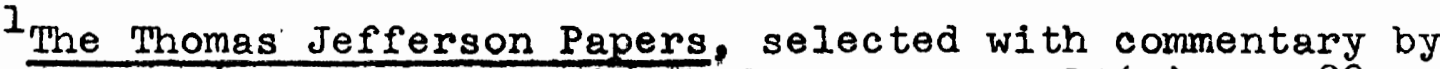
Frank Donovan (New York: Dodd, Wead \& Company, 1963), p. 88.

${ }^{2}$ John C. Miller, The Federalist Era: 1789-1801; (New York: Harper \& Row, 1960), p. 273. 
to execute the policies he and his close friend and political supporter, James Madison, proposed.

James Madison was fifty-one years of age when Jefferson appointed him Secretary of State. His political background was extensive. He was a coauthor of The Federalist Papers, an energetic member of the nations first Congress and a founder of the Jeffersonian Republican party in that Congress. 3 In 1797 Madison retired from Congress but not from his political concerns, soon becoming a dynamic force behind Virginia's opposition to the repressive Alien and Sedition Acts. In 1801 he forsook retirement, accepted the position of secretary , of State and commenced working on a foreign policy which combined prudence with moderation. 4

Rogether Jefferson and Madison formulated a foreign policy based on economy, isolationism, and westward expansionism. One of the first budgetary decisions was to reduce the number of countries with which the United States officially conducted diplomatic relations. 5 Embassies in Lisbon, Berlin and The Hague were closed, while ministries were maintained in Spain, Franee and England. To his former Secretary, William Short, Jefferson wrote on October 3, 1801, "We call

$$
\begin{aligned}
& { }^{3} \text { Smelser, p. } 186 . \\
& 4_{\text {Malone, p. } 52 .} \\
& 5_{\text {Ibid., p. } 102 .}
\end{aligned}
$$


in our diplomatic missions, barely keeping up those to the most important nations." 6

These policies reflected a move toward economy and isolationism. Isolationism protected American interests while Eupope engulfed helf in policies which required rorce and needlessty absorbed the energies of nations. In Jefferson's First Inaugural Address delivered March 4, 1801, he referred to the United States as the "strongest government on earth," who was "engaged in commerce with nations who feel power and forget right." America was far from Europe and thus "kindly separated by nature and a wide ocean from the exterminating havoc of one quarter of the globe; too high-minded to endure the degradations of the others; possessing a chosen country, with room enough for our descendants to the thousandth and thousand th generation." 7

The U. S. Government was capable of developing economicalIy and maintaining her republican principles if not encumbered by European alliances and demands. With these nations the

${ }^{6}$ Writings of Thomas Jefferson, eds. Andrew A. Lipscomb and Albert EIlery Bergh (washington D. C.: The Thomas Jefferson Memorial Association, 1903), vol. 10, p. 287. (Hereafter referred to as Jefferson.)

\section{Inaugural Addresses of the Presidents of the United} States from George Washington to John F. Kennedy, (Washington D.C.: U. S. Government Printing Office, 1961), pp. 14-15. (Hereafter referred to as Inaugural Addresses.) 
States endeavored to enjoy "peace, commerce, and honest friendship," but "entangling alliances with none." 8 Ethics were to control foreign affairs, for Jefferson in his Second Inaugural Address asserted:

We are firmly convinced, and we act on that conviction, that with nations, as with individuals, our interests, soundly calculated, will gver be found inseparable from oursoral duties.9

Jefferson:s moral view toward foreign affairs did not preclude his dreams of westward expansion. As early as 1786 he wrote:

We should take care not, to think it for the interest of that great continent (South America and its appendages) to press too soon on the Spaniards. Those countries cannot be in better hands. My fear is that they are too feeble to hold them till our population can be sufficiently advanced to gain it from them piece by piece. The navigation of the Mississlppi we must have. This is all we are as yet ready to receive.10.

His view of the Spaniards as stewards of future American territory allowed him to approve of the Pinckney Treaty of $1795 .^{11}$ For the present the status quo of Louisiana was adequate since the free navigation of the Mississippi and the right to deposit at New Orleans were terms of the treaty. Americals future was bright and her possible accomplishments were unlimited. When ready, she would assume control

8 Inqugural Addresses, p. 15.

9 Francis $w_{\text {. Hirst, Life and Letters of Thomas Jefferson }}$ (New York: Macmillan Company, 1926), pp. 405-406.

${ }^{10}$ Peterson, pp. 745-746.

${ }^{11}$ Sprague, p. 273 . 
of western lands not presently under her jurisdiction. While Europe quarreled and squandered her energies on useless, feeble and politically immoral activities, the United States would firmly, but cautiously, assert herself. An examination of Jefferson's foreign policy led Paul A. Varg in the Foreign Policies of the Founding Fathers to accuse Jefferson of constructing a "policy of unilateralism that paid scant attention to the legitimate interests of other nations." 12 What varg perceived as legitimate interests, Jefferson regarded as degrading alliances designed by European countries to further their power and wealth. These plans for self-aggrandizement were secondary in importance to the economic goals and republlcan principles of the United States. Jefferson's nationalism was unilateral and paternalistic. European affairs should be ignored as long as they affected Europe alone; when European possessions adjacent to the states instituted or followed policies contrary to the interests of those states, American indifference ceased.

The rumor in the early months of 1801 that Louisiana and the Floridas had been ceded to France caused concern among the Trans-Appalachian farmers and American leaders including the President and the Secretary of State. On June 1, 1801, James Madison dispatched a letter to his personal friend, Governor James Monroe of Virginia. Madisan

$$
12 \text { Varg, } p .148
$$


relajed the ramor, docried its possibility and asked

Nonroe to cxanine the subject in its every aspect in order. to thinix of any ideas which could be of service to the nation. Eight days after this note was written, Madison sert to the American minister in Spain, Charles Pinckney, an official communication repeating the rumor and instructing bim to seak verification. 13 on April 13, 1802, following the confirination of the cession by Rufus King in Londor, Thomas

$\checkmark$ Jetfercon wrote a personal letter to Robert R. Livingston, the T. S. ninister in France, instructing him to also verify the rumor. According to the President, the cession reversed the political relations of the U. S. with France. Up to this point France had been regarded as a "natural friend" with whom there were no differences but when that nation acquired possession of New Orlears, she became an enemy of the United states. 14 Jefferson explained:

There is on the globe one single spot, the possessor of which is our natural and habitual enemy. It is New Orleans, through which the produce of three-eighths of our territory must pass to market, and from its fertility it will ere long yield more than half of our whole produce and contain more than half of our inhabitants. Frarce, placing herself in that door, assumes to us the attitude of defiance. ${ }^{2}$

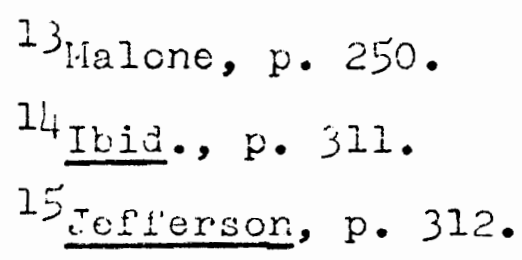


Having France as a neighbor presented immediate problems whereas spain had been tolerated. Jefferson continued:

Spain might have retained it quietly for years. Her pacific dispositions, her feeble state, would induce her to increase our facilities there so that her possession of the place would be hardly felt by us, and it would not, perhaps, be very long before some circumstance might arise, which might make the cession of it to us the price of something of more worth to her. Not so can it ever be in the hands of France: the impetuosity of her temper, the energy anu restlessness of her character, placed in a point of eternal friction with us, and our character, which, though quiet and loving peace and the pursuit of wealth, is high-minded, despising wealth in competition with insult or injury, enterprising and energetic as any nation on earth; these circumstances render it impossible that France and the United States can continue long friends, when they, meet in so irritable a position. 16

Jefferson suggested to Livingston that one possible solution to the immediate problem was an alliance with England:

The day that France takes possession of New Orleans, fixes the sentence which is to restrain her forever within her low-water mark. It seals the union of two nations, who, in conjunction, can maintain exclusive possession of the ocean. From that moment, we must marry ourselves to the British fleet and nation. We must turn all our attention to a maritime force, for which our resources place us on very high ground; and having formed and connected together a power which may render reinforcement of her settlements here impossible to France, make the first cannon which shall be fired in Europe the signal for the tearing up set-i. tlement she may have made, and for holding the two continents of America in sequestration for the common purposes of the United British and American nations.17

$$
\begin{aligned}
& \text { 16 Jefferson, p. } 312 . \\
& 17_{\text {Ibid., p. }} 312-313 .
\end{aligned}
$$


If France assumed possession of New Orleans, then an alliance with England became necessary. With the threat of an Anglo-American alliance the benefits France obtained"by taking control of New Orleans were negligible. If France justified possession by mintaining that Louisiana was necessary as a wartime depot for the West Indies, Jefferson argued that since the island of Now Orleans was not needed for supplies in times of peace, it could not be depended upon in war; its location made it susceptibat to easy interception. 18

Jefferson was careful to propose a possible resolution. of this conflict of interests. The cession to the United States of the island of New Orleans and the Floridas would remove "the causes of jarring and irritation between us," and "would, at any rate, relieve us from the necessity of taking immediate measures for countervailing such an operation by arrangements in another quarter." However, this arrangement would not eliminate the possibility of an American quarrel with France since she would remain a neighbor and her strength and desire for power would sustain tensions. 19

After depicting the tension the cession had created, suggesting an alliance with England and questioning the value

$$
{ }^{18} \text { Jefferson, } p \cdot 314 \cdot
$$


of Louisiana to France, Jefferson urged Livingston to confront French officials with these considerations. Time was with the American minister since troops dispatched to the island of Santo Domingo would most likely proceed to Louisiana only after they conquered the island. Jefferson explained:

If this were the arrangment, it will give you time to return again and again to the charge. For the conquest of St. Domingo will not be a short work. It will take considerable time, and wear down a great number of soldiers.20

The previous reference to an alliance with England was repeated by Jefferson and Madison in their conversations with British representative Thornton and French chargé Pichon. Pichon was led to believe that Jefferson was quite willing to prepare for a possible Anglo-American rapprochement. 21 This inclination, coupled with repeated expressions of the inadvisability of the cession, 22 convinced Pichon of America's intent to oppose the cession and he sent reports to France revealing American opposition to French actions.

Historian Dumas Malone believes that these conversations possibly were more influential than the petitions of American ministers in Europe. 23 since influence is difficult to

$$
20 \text { Jefferson, p. } 315 .
$$

22 George Dangerfield, Chancellor Robert R. Livingston of New York (New York: Harcourt, Brace \& Company, 1960), p. 352; Malone, pp. 292-293.

$$
23 \text { Malone, p. } 291 .
$$


measure, one can certainly propose that reports from Pichon and Thorton made the statements of American ministers more credible. Although in both instances the information originated with Jefferson and Madison, the European ministers in the U.S. were able to observe the reaction of the American citizenry and thereby verify the President's and Secretary of State's contentions.

While the Peaee of Amiens offered England and France a Iull in fighting, the United States confronted the gravest of diplomatic 24 To resolve this problem Jefferson and Madison continued to engage Thorton and Pichon in private conxersations while American diplomats abroad utilized their abilities and opportunities to verify theccession, determine its extent and effect an agreement insuring American interests. The outcome could not be an entangling alliance since that would interfere with America's political and moral development but an arrangement that removed the threat of French occupation of New Orleans without committing the United States to unreasonable and stifling French demands. These qualifications served as guidelines for American diplomats in Spain, England and France. Since the diplomatic corps had been reduced, the responsibility of obtaining information and negotiating a settlement with France fell only to Charles Pinckney in Madrid, Rufus King in Eondon and Robert R. Livingston in Paris.

$$
24_{\text {Malone, p. } 239 .}
$$


CHAPTER III

\section{THE AMERICAN DIPLOMATS}

Charles Pinckney's personal history was closely linked to the politics of South Carolina and the formation of the United States Constitution. In the late $1780^{\prime} \mathrm{s}$ the South Carolina legislature appointed Pinckney one of four delegates to the Constitutional Convention at which he supported the proposed Cunstitution. I After the Convention, Pinckney served as Governor of South Carolina and in 1798 was elected to the nation's Senate. 2 During the Presidential election of 1800 it appeared that Thomas Jefferson might not receive South Carolina's support but her votes were forthcoming. Although events leading to the Jefferson victory in South Carolina remain uncertain, Charaes Pinckney assumed the credit for the voting results. In his letters to Jefferson, Pinckney endeavored to impress upon the President that his national victory, not just South Carolina's, was the direct result of

I Marvin R. Zahniser, Charles Cotesworth Pinckney: Fourding Father (Chapel Hil North Carolina: University of North Carolina Press, 1967), p. 87-92.

Ibid., p. 206 . 
Pinckney's efforts in Columbia, South Carolina. ${ }^{3}$ Writing to Jefferson on Decembor 2, 1800, before it was known that the election had resulted in a tie between faron Burr and Jefferson, Pinchey recounted:

ive have had a hard asd arduous strisgle and I found that as trere were no hopes Irom Philadelphia end it depended upon our state entirely to secure Your Election ana that it would be almost death to our hopes for me to quit Columbia, I have remained until it is over and now pemit re to congratulate You my dear sir. 4

Due to the tie the election was transferred to the Fouse of Representatives. When the House elected Jefrerson in Febriary, the new President revarded Charles Pinckney for his clained efforts by appointing hin tre Arerican minister to Spain.

Shoptly after his arrival in Spain, Pincrney received a letter from Jemes Madison dated June 9, 1801 which relayed the rumors of the cession. Since the extent of the cession or the considerations upon which it was made were unimown, Pincluey was assured that the subject deserved his "vigilant inquiries." Spanish motives were not obvious but it appeared that the French betrayed their disinterest in procuring land in North Amesica by acquiring Louisiana. The shift nay have been due to French jealousy of the United States'. partiality toward Great Britain; French alarm that England intended to

$$
\begin{aligned}
& 3 \text { zanniser, } p \cdot 227 . \\
& 4 \text { xbid., p. } 227 .
\end{aligned}
$$


capture the mouth of the Mississippi River; or French concern that the United States might form an alliance with England. Although the chief difficulty did not lie with Spain, Madison instructed Pinckney to learn whether the cession had actually taken place. 5

Despite Pinckney's efforts, the Spanish Secretary refused to confirm or deny the rumor of trie cession. A Letter trom Madison dated May 11, 1802 reveals that Pinckney had either failed to share his findings with the secretary of state or had nothing to write. Madison appealed to the American minister:

We are still without a line from you since your arrival at Madrid, and feel an increasing solicitude 6 to hear from you on the subject of Louisiana. 6

Although the cession had been confirmed by Rufus King's November dispatch of a copy of the treaty to Jefferson and Madison, the knowledge of Spanish intentions remained valuable since a reversal of the transaction was possible. If Louisiana passed into french hands, rinckney was instructed to make some arrangement whereby the Floridas and New Orleans were ceded to the United States. These instructions extended

5 American State Papers, Foreign Relations (Washington D.C.: Gales and Seaton, 1832), Vol. 2, p. 510. (Hereafter referred to as ASPFR:)

6 Ibid., p. 517 . 
Pinckney's responsibilities and Madison carefully pointed olit that this was evicience of the increased importance of the mission. 7

In regard to the Floridas both Nadison and Pinckney assumed that they were not included in the cession. By offerirg to guarantee the remaining Spanish colonies west of the Mississippi, Pinckney hoped to obtain the Floridas from Spain. Fe also pointed out to Spanish leaders that the floridas had never been a productive colony and with Louisiana under French cortrol, trey would even be less valuable. However, the Nobile River and others east of the Mississippi River were important waterways for Americans residing on their upper courses and, therefore, the Flcridas would be valuable to the United states despite their proximity to French possessions. 8 Madison's changed opinion regarding the status of the Florias is reflected in his letter of July 26, 1802 to Charles Pinckney. He now thought the Floridas and New Orleans were included in the cession. If so, it was unnecessary for Pinckney to ascertain the price Spain would accept for those possessions. Therefore, for the present the cession would remain the object of negotiation in France. Pinckrey's efforts

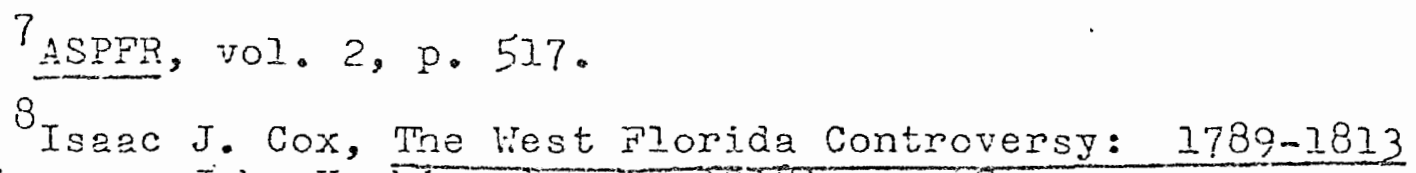


were not to be teminated as they could be used to cultivate good relations with Spain which might encourage Spanish leaders to speak to French officials on bchalf of American interests. Also it was possible that in the future Spain might be extricated from her agreement with France and again be free to dispose of the territories presently constituting the cession. 9 Nadison in a letter dated January 18, 1803 reiterated that negotiations could likely be accomplished in Paris and Pinckney was to be informed of these negotiating efforts in order to cooperate if the occasion demanded coaction. 30 It was not until 1804, when the question concerning the inclusion of West Florida in the Louisiana Purchase arose and Spain denied its transfer, that Pinchney played a major negotiating role. Ifonroe was to join pinckney in spain and together they were to negotiate for the Floridas. However, Pinchney exceded his instructions by not waiting for Monroe before pressing matters in Madrid. He raised troublesome questions about the floridas, criticized the Spanish for their failure to ratify a Claims Convention negotiated in 1802 between Spain and the U. S., and issued blundering statements about the liobile Act, a statutory claim to the

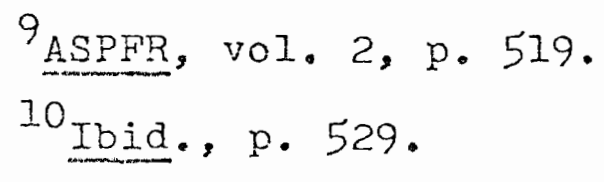


navigation of the rivers in West Florida. These actions made the ambassador diplomatically ineffective. ${ }^{11}$ when lionrce did join Pinchney, their joint efforts failed to secure Vest Florida.

Although Pinckutey:s assightrnent was not to a place where the most important negotiating efforts were underivay, he was nevertheless responsible for the securement and speedy dispatch of intormation resarding the cession to Madison. - Some communication was to be expected, especially at such a critical time, but it was not forthcoming. Later he violated his instructiors by proceeding before Monroe's arrival. His negligence and impetuosity hincered diplomatic success. $\checkmark$ Forturately Jefferson and raaison in the years 1801 to 1803 did not need to depend on Charles rinckney as their only source of information. It was Rufus King, not Pinckney, mo dispatehed inuch of the requested information and confirmation of events.

Rurus King's political experience was extensive and his political afiiliation controversial. When Gecrge bashington became President and asked King to serve as Secretary of State, King declined. ${ }^{12}$ In the late 1790 's he had been a

\section{$1 I_{\operatorname{Varg}}, \mathrm{p} .159$.}

12 Eradicud Perisins, The First Kapprochement: Englard $\frac{\text { and the United States (Philadelph }}{\text { Pennsylvania Press, I955), p. } 37 .}$ 
member of the inner circle of Figh Federalists who had encourged war with France and supported an alliance with Englard. 13 It was while serving as a Federalist senator from New York that King applier for the position of rinister Plenipotentiary to Great Britain. Fis application for appointment was sent through Alexander Hamilton to Secretary of State Timothy Pickering with Hamilton's recommenation attached. It read:

If we had power to make a man for this purpose, we could not imagine a fitter than Mr. King. $1 \frac{1 !}{4}$

On May 19, $1796 \mathrm{Kjng}$ was officially nominated to the post. Following Congressional consent, King traveled to Englanà and assumed his diplomatio responsibilities. vrile in Pngland, prior to the Presidential elestion of 3800 , King intimated in his letters that he was thinking of returning home if the Republicans were victorious. Wen Jerierson was elected, Hing believed that the policies of the new Fresident would not allow him to bring his negotiations regarding the Revolutionary war debts to a satisfactory conclusion. King recognized that the negotiations could not be completed beione Jerferson's Inauguration but since he devoted so much

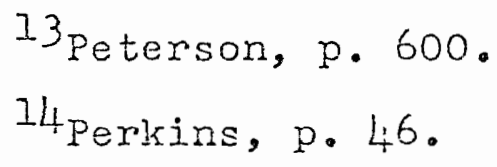


time to these talks, he determined to continue his eiforts until Jerierson relieved him. ${ }^{15}$

The status of King's assigment remained unclear even as late as Kay 27, 1801, when Iriend and fellow-New Yorker, Robert Troup, wrote Rufus ring the following zppraisal:

We all believe that it is not irr. Jerterson's present plan to supersede you. Hr. Yorris seems confident he will not do it. And yet the course thus far pursued by lir. Jefierson with resard to removals has strong marks of an entire devotion to party.

Within the Republican ranks there was extreme pressure to remove King, with one of the earliest and most ademant acrocates being Jarres ronroe of Virginia. Fearful of the appointment of Federalists to public offices and receptive to the objections of fellow Virginians, l:onroe raised the guestion of the propriety of retaining Rufus king in a letter cated April 29, 1801 to Jefferson:

There is another object to which I found the attention of the Republicans here, comprising many from the country who are attending our court of appeals \& tre federal Ct., drawn with much rore anxiety, that is the propriety of continuing Yr. K. (King) at the British Ct.17

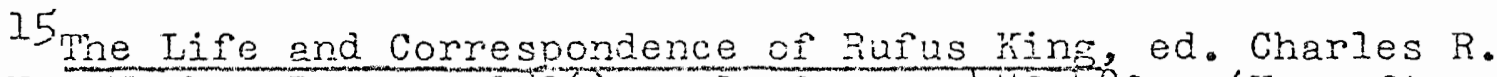
King (ITe York: Putnam, 1896), vol. 3, pp. 482-483. (Hereafter referred to as Xing, vol.3.)

$$
\text { 16 Ibid., pp. 458-459. }
$$

17 mae Writings of James ronroe. ed. Stanislaus $M$. Hamilion (iven Yort: Rnickercocker Press, 2900), vol. 4 , p. 279 . 
On the next day, Monroe wrote another letter to Jefferson which, after reconsideration, he decided not to send. In this draft dispatch, Monroe clearly itemized his objections to King's retention as Kinister Plenipotentiary to Groat Britain:

That as every calemity foreign \& domestic which we have experienced has proceeded from Great Britain, a person known to be friendly to her interests, acquainted with our interior, able to guide her councils \& plan her measures against us, ought not to be left there under the present administration....

His continuance there will be consjdered by that govermment as a proof that the present administration does not think itself solidly iounded at home, that it dreads the English power \& is resolved to keep terms with. it at all nazaras. 18

Four days later Monroe withdrew his objections, declaring that when it came time to act on King's recall, it wes a.far more delicate matter than he had previously imagined. 19 In the $1790^{\prime}$ 's Monroe had been the object of Pederalist browbeating and to avoid following their "inworthy example" and indulging his "private resentment at their expense," he reversed his position. 20

Despite Monroe's initial suggestion, Jefferson showed no disposition to remove Rufus King, but rather left the time

18 Monroe, p. 281.

19 Ibid., p. 279.

20 Ibid., p. 280 . 
of King's resignation up to the minister himself. 21

Instructed to continue negotiations for a convention regarding private American debts to British creditors, King followed these orders while acquiring information about Europe and Loujsiana.

King diligently recorded for Madison the state of European affairs as it affected the Peace of Amiens, the confirmation and extent of the rumored Louisiana cession, the question of French occupation and settlement of Louisiana, and the possibility of England working for the benefit of the United States at the peace talks with France.

On April 25, 1801, King described for Madison the events in Northern Europe including British activities in Copenhagen and Egypt, the character and view of the new Inperor Alexander of Russia and the conduct of the King of Sweden. In early June he commented on the French amy's diminishing chances to maintain control of Egypt and alluded to French preparations to invade 3riuish Iands. 22 To Madison, King explained the importance of this iniormation:

I mention these detached facts to prove that the negotiation, which still goes on by courier between Paris and London, must wait for and depend

\footnotetext{
2l The Life and Correspondence of Rufus Kine, ed. Charles R. King (New Tork: Putnam, 1896), vol. 4, p. 201. (Hereafter referred to as King, vol. 4.)$$
22 \text { Ibid., vol. 3, pp. } 436-473 .
$$ 
upon events still undecided in the frorth, as well as in the South, and that all conjectures concerning its result must therefore be illusory. 23

The confirmation of the Louisiana cession and its extent deserved and received King's immediate attention. By November 20 th King had learned th at the Fifth Article of the Treaty of San Lorenzo confirmed the cession of Louisiana to France. 24

The extent of the cession was unknown; it remained impossible to determine if it included New Orlears and the Floridas. On November 25th Mr. King conferred with British Secretary Lord Hawkesbury and received a copy of the treaty. 25 Neither the laneuage of the treaty nor the interpretations of Lord Hawiesbury made clear the extent of the cession. King remarked:

Spain had certainly ceded Louisiana. Sut he ITord Fawkesbury7 did not exactly comprehend the Territory included under that Term ĹLuisiana 7.26

* King expressed the opinion to Lord Hawkesbury that the term "Louisiana" referred only to lands west of the Mississippi, not New Orleans and the Floridas. The Treaty of Paris of 1762

$$
\begin{aligned}
& 23 \text { King, vol. 3, pp. 437-438. } \\
& 24 \text { Ibid., vol. 4, p. } 15 . \\
& 25 \text { Ibid., p. 15-19. } \\
& 26 \text { Ibid., p. 18. }
\end{aligned}
$$


$\checkmark$ placed the land east of the Mississippi River under England's control and therefore only the land west of the River was truly "Louisiana". 27 If, however, the Floridas and lew Orleans had been given to France, the rights and privileges of Americans relying on the rivers in the Floridas and the right of deposit at New Orleans were definitely in jeopardy. 28 Another aspect of the cession which occupied King's efforts involved Frenci plans to occupy and colonize Louisiana. On November 20, 1801 King expressed the view that the French forces who were preparing to proceed to Santo Domingo were not to be emplojed later in the occupation of Louisiana. 29 Confirmation that no part of the expedition was traveling toward Louisiana came to the American minister through Lord Hawkesbury on November 25, 1801.30 Fowever, on February 5, 1802, King wrote to Madison that it had been "definitely settled" and a colony under the direction and command of General Bernadotte was to be sent to Louisiana and Florida. The ceparture depended upon the affairs in Santo Domingo. The character of the colony must have disturbed Jefferson and Nadison, for King explained thet Louisiana, Guiana, and

$$
\begin{aligned}
& 27 \text { Iing, vol. 4, p. } 18 . \\
& 28 \text { Ibid., vol. 3, p. } 469 . \\
& 29 \text { Ibid., vol. 4, p. } 15 . \\
& \text { 30 Ibid., p. 19. }
\end{aligned}
$$


the desert island of Tristan de Cunha had been spoken of as places to send "the rebeliious and untractable negroes and people of color" from St. Domingo and other French colonies! 31

In adition to consulting Lord Hawkesbury about the extent and ramifications of the cession, Rufus King inquired whether it altered the right of Americans to navigate the Mississippi River, thereby negating the guarantees England had made to the U. S. at the end of the Revolutionary War. King's confidential letter to the British Secretary reviewed the Treaty of Paris of 1783 which assured the right of British subjects and American citizens to navigate the river from its source to the Gulf. King sought to learn if the British govermment had received any communications from Spain or France regarding the cession and if, in responding to these commications, England had impaired the navigation rights bequeathed to Americans. 32 Lord Hawkesbury's confidential reply came in May 1802. The British official testified that no such communication rad been received and His Majesty had not "in any manner, directly or indirectly acquiesced in or sanctioned this cession." As to the navigation rights, Lord Hawkesbury assured King that with the cession, France probably obtained possession of the Treaty of 1783 and if she

$$
\begin{aligned}
& 31_{\text {ASPFR, }}, 513 . \\
& 32_{\text {King, vol. } 4, \text { p. } 109 .}
\end{aligned}
$$


chose not to violate this agreement, these rights of British subjects and American citizens would be respected. 33

Although England considered the cession "a measure of the greatest consequence," they would not speak out against the cession or promote American rights to navigate the Mississippi River. 34 Being willing to clarify aspects of the cession was the extent of British aid and thus direct diplomacy with French leaders was America's only hope.

When the Convention with England was signed in January I802, Rufus King dispatched his official letter of resignation on Augist 5, $380 ?$ to the Secretary of State and gave April, 1803 as the termination date. 35 In the Iate summer and early autumn of 1802, King and his family traveled on the Continent for a few weeks. Traveling to Paris, King consulted with the American minister, Robert Livingston, but no account of their conference was recorded. 36 King's career as a $\rightarrow$ diplomatic agent of the United States was ending. He had endeavored to confirm the cession's existence, determine its extent and anticipate its consequences. However, the resporsibility of defending American rights and negotiating for the

$$
\begin{aligned}
& 33_{\text {King, vol. } 4, \mathrm{p} .123 .} \\
& 34_{\text {ASPRR, p. } 516 .} \\
& 35_{\text {Malone, p. } 97 ; \text { King, vol. 4, p. } 200 .} \\
& 36_{\text {King, vol. 4, p. 179. }}
\end{aligned}
$$


Floridas and New orleans with the recipients of the cession, the french, fell to the newly-appointed American minister in France, Robert R. Livingston.

Robert $R$. Iivingston had been a judge of an admiralty court, a justice of the New York Supreme Court, a member of the Stamp Act Congress and a delegate to the continental Congress serving on the committee of five assigned to draft the Declaration of Independence. 37 Appointed First Chancellor of New York, he administered the oath of office to George Washington on his First Inauguration. He served as Chancellor

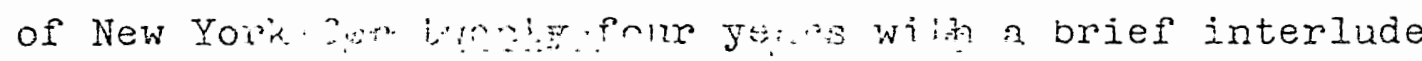

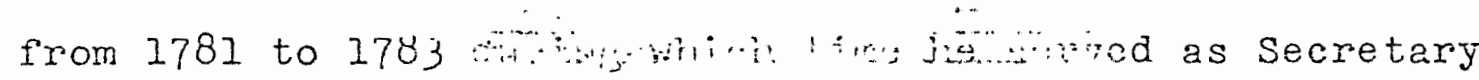
of Foreign Affairs. 38 Dully Trin Adams's administration, Iivingston was averse to the Alien and sedition Acts and .... labored to get the Virginia Resolutions adopted by the New York legislature. 39 When Thomas Jefferson believed in December 1800 that he had been elected President, he began to select a Cabinet and asked Iivingston if he would serve as the secretary of the Navy. Jefferson wrote:

It is essential to assemble at the autset persons to compose our administration, whose talents, intefrity and revolutionary name and principles may inspire the nation at once,

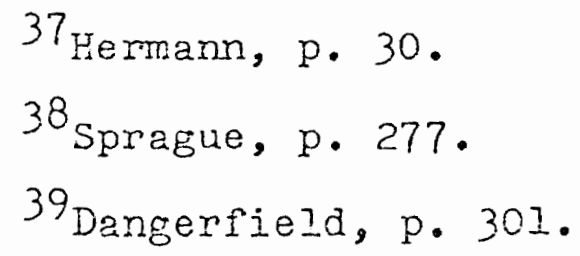


with unbounded confidence. 40

Livingston declined. When the Presidential election was resolved by the House of Representatives in February 1801, Thomas Jefferson renewed his requests and among them, the query to Livingston to serve as Minister Plenipotentiary to France. Realizing the sacrifices the Chancellor would make in accepting the position, Jefferson declared:

Though I am sensible of the advantages derived from your talent to your particular state, yet I cannot suppress the desire of adding them to the mass to be emploped on the broader scale of the nation at large. 4 .

Iivingston accepted and forthwith received a congratulatory note from the Governor of Virginia who would later cast a pall over livingston's ministry in France. Monroe exclaimed:

Permit me to avail myself of the opportunity furnished-by this young gentleman to assure you of the high satisfaction I have in Your appointment to France, \& to add my sincere wishes that your mission may prove as grateful \& honorable to yourself as the auspices under which it is undertaken give you reason to expect it may be. 42

Jefferson considered Iivingston's political asset to be his overall pro-French attitude despite his revulsion to the French Terror. 43 His personal strengths included his ability to read French well, his diligence and self-confidence.

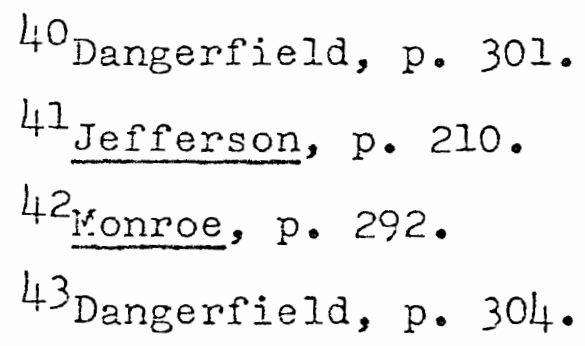


A major weakness was his inability to speak French fluently due to his deafness. 44 of this condition William Short, private secretary to Jefferson when he was ambassador to France, wrote that Livingston was "unfortunately, so deaf that he will have to transact all his business by writing." Despite this handicap, Short raintained that the recently appointed minister was "an amiable and honorable man."45 To Robert R. Livingston fell the responsibility of negotiating with the French for the Ploridas and New Orleans. To be the Minister Plenipotentiary to France was in 1802 the most demanding position in American diplomatic circles. Napoleon was fighting for his western empire and had already secured Louisiana. For the United States to oppose the cession and French expansionism mijitarily was unthinkable and so America had to protect her rights diplomatically. To think that the U.S. could compel France to alter her foreign policy and to make concessions was sheer folly but those were Livingston's instructions. By engaging in persistent argument and presenting creative alternatives, Livingston hoped to change Napoleon's mind and remove France as a menace to the burgeoning United States.

$$
\begin{aligned}
& 44 \text { Malone, p. } 250 . \\
& 45 \text { Jefferson, p. } 288 .
\end{aligned}
$$


CEAPTER IV

\section{PROBLPUS IN PARIS}

Before sailing for France Livingston receivea explicit instructions from the Fresident and Secretary of State. The instructions stated that it was essential to confirn tise cession and if it had not occurred, to stress to French leaders that the proposed cession violated Arerican interests and threstened pranco-kmerian relations. Is Iouisiana had been ceded, Livinaston was to refrain from irritating the French and to learn is they were viling to twansen $\checkmark$ the Froricas to the U. S. I Totring was to be dore which Noula "unresessarily irritate our îture neighiors, or checr the literality which they may be disposed to exercise in relation to the trade and navigation trrough the nouth of the "ississippi." The continuance of existing Spanish policies regarding the Kississippi River was comercially vital and had to be maintained through diplometic efforts. ${ }^{2}$ Girded with these instructions, Iivinsston immediately endeavored to fulfill them upon reaching Paris on December 3 . One week later he dispatched a letter to Madison which

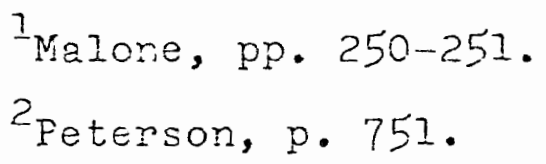


contained conclusions he had reached after gleaning information from French officials. Livingston believed that the Louisiana cession had taken place although Talleyrand only admitted that it "had been a subject of conversation but notring had been conoluded, or even resolved on in that affair." 3 In this conversation, and others, French Minister Tallejrand remained uncomunicative and thus made Livingston's ministry less effective. For this reason Jefferson and Madison continued to condact their negotiations through the French chargé pichon, who translated the American position so effectively to Talleyrand that the need to forward explicit instructions to Livingston was lessened. 4

While serving as American Minister to France, Livingston's negotiations suffered from inadeguate instructions ana poor relations with the French Hinister of tre Exterior Affairs, $\checkmark$ Nonsieur de Talleyrand. Insufficient instructions from the Fresident and Secretary of state plagued Ijivingston from December 1301 to Monroe:s arrival in tpril 1803. The American minister was virtually neglected in the winter of 1801 to 1802 although he was attempting to learn the status of the Floridas and New Orleans. 5

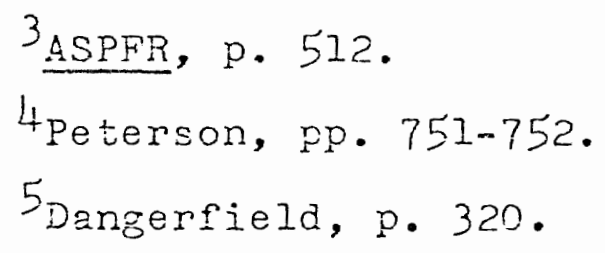


On January 13, 1802, Livingston sent a copy of the terms of the Treaty of San Idlefonso to Nadison. ${ }^{6}$ Neither the treaty nor French oficials clarified whether the Ploridas were included in the cession. Livingston believed they were and Jefferson agreed. In April the President aùised Livingston to press for a French cession of the Floricas and New Orleans to the U. S. but to take his time since France could not move anead with her plans for Louisiana until Santo Domingo's conquest which, Jefrerson trought, was some time off.7 Instructions to Livingston remained the same in fiay with the exception that he was instructed to deternine what price was acceptable to France for the Floridas and New Orleans. 8 Nadison told Iivingston:

The President wishes you to devote every attention.to this object, and to be. frequent... and particular in your communications relating to it. 9

No offer was authorized by Jefferson or Madison and Livingston, wanting some idea how much to propfer, inquired of the Secretary of State on July 30, 1802:

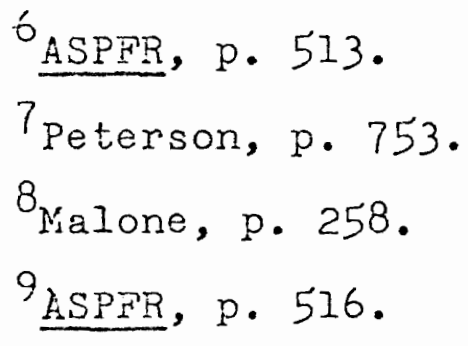


I am sorry that you have not communicated to me what are precisely the utmost limits of the sum I may venture to offer in cash, or in our own demands. 1

Less than two weeks later Iivingston repeated his request to Madison:

I am very much, however, at a loss, as to what terms you would consider it as allowable to offer, if they can be brought to a sale of the Floridas, either with or without New Orleans: 1...7 I may, perhaps, carry my estimate of them too high; $\ldots . .7$ I trust, however, that you will give me some directions on this head, and not leave the responsibility of offering too much or too little entirely at my door. II

After learning that the Floridas were not ceded to France in the Treaty of San Idlefonos, the American minister still sought to learn what offers he could make. Writing to Madison on November 2, 1802, Livingston implored:

I therefore pray you to be explicit in your instructions, and in your replies to some questions that I have asked jou relative to this subject in my former letters, since $I$ an at present wholly unauthorized as to any offers that it woula be proper to make; and we certainly do not expect to receive this country, or any interest in it, as a free gift. 12

Five months following his first appeal regarding the amount he could offer, Livingston was still awaiting instructions

$$
\begin{aligned}
& 10 \text { ASPFR, p. } 520 . \\
& 11_{\text {Ibid. }} \text { p. } 520 . \\
& 12_{\text {Ibid., p. } 526 .}
\end{aligned}
$$


in December when he wrote, "Pray be explicit in the amount of what I may offer..." 13

Neither Jefierson or Madison responded to these requests and no new major instructions came from Washington $D$. $\bar{c}$. from May 1802 to February 1803. In 1ate January 1803 Livingston shared his feelings of alienation:

As to myself, I am left wholly without any precise instruction how to act, or whet to ôfier.

I confess to you I see very little use for a minister here, where there is but one will and that will governed by no object but personal security and personal ambition: were it left to my discretion, I should oring matters to some positive issue, or leave them, which would be the only means of bringing them to an issue.14

Only when Monrce arrived did Livingston acquire adaitional instructions. The possible reasons for an absence of explicit instructions are numerous. Jefferson and Madison may have had no new information to share with Livingston. Without unconditional confirmation of the cession and absolute knowledge of its extent, Iivingston's original instructions remained adequate. As will be seen, Livingston's relationship with Talleyrand was not amiable and iropefore the President and Secretary of State provided the irench chargé Pichon with information which was efficiertly transmitted to Talleyrand thereby eliminating Livingston as a

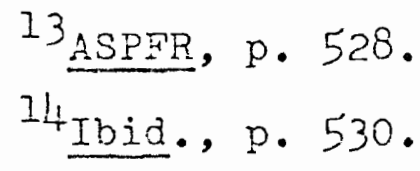


necessary intermediary. Finally, Jefferson and Madison believed they had time to resolve the problems of the cession. France could not proceed to colonize Louisiana until French control rad been restored on Santo Domingo. Feanwile, livingston sensed an urgency to the situation; the finerican minister believed that the reed to confirm the cession snd resolve any problems stemming from it was imrediate. This variance in attitudes created friction between Iivingston and his superiors in Washington $D . C$. George Dangerfiela explains:

In Washington, the tercercy was to behave as if everything could be sottlea in tire, but always to brandish, es it were, behind one's back, some half-concealed thunderbolt: in Paris, the Ifinister's peremptory character compelled him to act as il there was almost ro tirae left. In the end, these tendencies were united in a mutual triumph: but the misunderstandings engerdered by them were acute and lasting. 15

Livingston felt an urgency to complete negotiations but experienced irustration as re found his schedule was tedious. Honday evenings were spent at lladame de Forra's and on Tuesdays were receptions at the second and rirird Consuls. Every Wednesday a reception was held at Monsieur de Talleyrand's and on Thursday the "Erand circle" was held at the First or Second Consul's. Fridas saw a reception at Livingston's own legation in the rue Trudon with Saturday 
providing the occasion for a party at either the Minister's of War or the Minister's of the Interior residence. At least two days each month, every diplomat was expected to attend the parade at the Tuileries at noon followed by the levee from $2 \mathrm{p} . \mathrm{m}$. to $5 \mathrm{p} \cdot \mathrm{m}$., dinner at 5:30 and a reception lasting at least until 11 p.m. when the First Counsul departed. 16

Considering these social events time-consuming, tedious and unproductive, Livingston sought opportunities for serious negotiation. When time was so precious and results so meager, the American minister experienced anxieties unknown to those separated from the scarcity of opportunity by anocean spanning thousands of miles. The success or failure of Livingston's diplomacy was compressed into a lew encounters.

The absence. of explicit instructions can be attributed to several reasons: a lack of intormation, the adequacy of Livingston's initial instructions of september 1801 ,

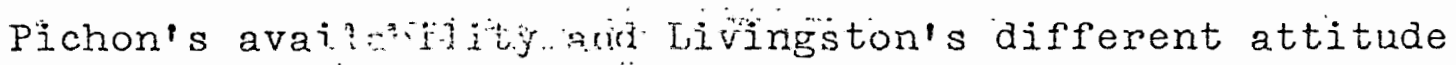
toward time ss orimpared to that of Jefferson and Madison. Despite this handicap, Livingston attempted to acquire information concerning the extent of the cession. In June 1802 he received a response to a letter he had written to the Spanish ambassador to France, Chevalier DiAzara on Nay 28, 1801. According to the Spanish ambassacor the Floridas had not been ceded but negotiations for them were still underway

$$
{ }^{26} \text { Dangerfield, p. } 340
$$


between France and Spain. ${ }^{17}$ on July 3 Talleyrand hinted to Livingston that Florida was not yet French. 18

In addition to securing information about the extent of the cession, Livingston tried to ascertain whether the United States retained the right secured by the Pinckney Treaty to navigate the Mississippi River. 19 Livingston inquired of Talleyrand on February 20, 1802 whether the cession affected the American right to navigate the Mississippi but the question went unanswered. 20 However, by February 26, 1802, Livingston had obtained assurance from a friend of the First Counsul that it was not the French intention "to obstruct the navigation of the Mississippi, or to violate our treaty with spain."2l

Concern that with the cession American might be denied their right of deposit at New Orleans compelled Nadison to write to Livingston on Way 1, 1802:

If a possession of the mouth of the Mississippi is to be added to other causes or discord, the worst events are to be apprehended.22

17 ASPFR, p. 519.

18 Dangerfiela, p. 329.

19 ASPFR, pp. 510-511.

${ }^{20}$ Ibid., p. 514.

${ }^{21}$ Ibid., p. 513.

22 Ibid., p. 516. 
To determine the status of the right of navigation and deposit Livingston wrote to Chevalier DrAzara on May 28 , 1802. Spain had assured the United States that no other nation would share the right to navigate the River unless by convention. Spain had agreed not to Exun-nevigation rights without some understanding on this subject with the U. S. Livingston also wanted to be assured that the right of deposit had not been violated. 23 He summed up his request to D'fuara by saying:

You will easily see, sir, that if a naked cession has been made to France, without attention to these articles, how ruch reason the United States will have to complain of the measure. 24

Chevalier D'Azara admitted that although the Floridas vere not included in the cession, but he provided no insight into the American rights of navigation and deposit. 25 lot until July 30 th did livingston forward to Madicon information acquired from the Spanish minister to Charles Pinchey. Iivingston's note bore the following comment:

If the King should think proper to cede Louisiana, he will take care that the interest of the United States shall not be affected by it. 26

It was a feeble assurance and the reply was not even frank enough to reveal the existence of the cession. While Dizara confirmed the cession by sayine the floridas were not

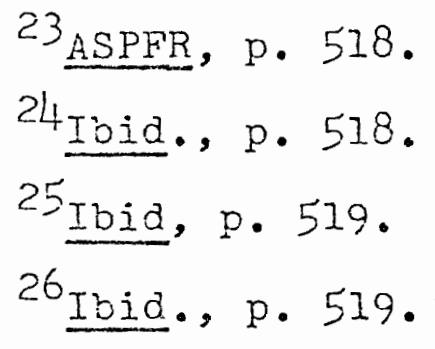


included, other Spanish and French officials failed to admit the cession even following livingston's dispatch of a copy of the treaty to Madison!

Another problem besetting Livingston was the strained relationship with the French Minister of Exterior Afiairs, Monsieur de Talleyrand, with whom he was compelled to work closely.

Talleyrand disliked not only Livingston but all Americans because of their role as outspoken critics and victins of the infamous $X Y Z$ affair during John Adams's Administration. Fleeing from the French Terror, Talleyrand had spent months in the United States. Of all the men he met while in America, he had been impressed only with the aristocratic AIexander Hamilton. 27 Not only did Livingston need to negotiate with a minister with a distaste for Americans but in order for his mission to be successful, he had to dedicate himself to forestalling Talleyrand's and Napoleon's efforts to establish a French empire in North America. To both these persons the possession of Louisiana vas essential to French expansion and empire. 28 George Dangerfiela $\checkmark$ describes the situation in which Livingston was placed:

$$
\begin{aligned}
& 27 \text { Dangerfield, p. } 313 . \\
& 28 \text { Ibia., p. } 314 .
\end{aligned}
$$


To extract concessions from the hostility of Talleyrand and the imperial dreams of the Consul would have been dificult enough if livingston had been given adequate powers: if he had had, that is to say, something definite and valuable to offer, As it wasmith his deafness, his inadequate French, his lack of advisers-he could not have seemed a very significant personage. Talleyrand, beneath his exauisite amenity of address, brought to his dealings with Livineston a painflu ar mory of almost imperceptible snubs and frail but deadly sarcasms. Behind the American Ninister, after all, there loomed neither armies, nor navies, nor wealth; neither the power to browbeat nor the means to bribe: he had only that indefinable something, that vague but vast threat, the future United States.29

The future of the United States was an intangible asset but a rore tangible advantage held by Iivingston in his dealings with Talleyrand was that the American "simply did not conceive that any man was a finer social specimen than himself." Mis belief in his personal value led to Iivingston's persistence in pressing concessions and mentioning French debts. 30 Iivingston relentlessly insisted that both France and Spain might mutually benefit by ceding the Floridas to the U.S. $3 I$

On December 11, 1801 Livingston mentioned to Talleyrand that the cession of the Floridas and New Orleans could serve as a way of paying French debts to the U. S. Palleyrand

$$
\begin{aligned}
& 29 \text { Dangerfield, p. } 319 . \\
& 30 \text { Ibid., pp. } 320-321 . \\
& 31_{\text {ASPFR, p. } 512 .}
\end{aligned}
$$


replied, "...none but spendthrifts satisfy their debts by selling their lands." Again Talleyrand maintained that the Floridas and New Orleans were not French and therefore "not ours to give." 32

Nine days later the American minister was again unsure whether the cession had even taken place but from formal interviews and informal receptions had absorbed the temper of Bonaparte's plans and concluded that if France had obtained the Floridas in exchange for Parma and Piacenza, she would never cede them to anyone; Bonaparte was intoxicated with his plans for a western empire. 33

Frencin debts were frequently mentioned by the Arnerican minister. These American claims viere for embargoes, the seizures of cargoes in French ports and arbitrary purchases accumulated from 1793 to 1800 and not canceled by the Convention of 1800. Legitimate claims may have amounted to $\$ 5,000,000$ with American citizens entering into partnership with French citizens considered denationalized as far as claims were concerned. 34 In response to Livingston's continual references to these claims, French officials admitted the justice of or claims but did not pay them. How ably livingston used

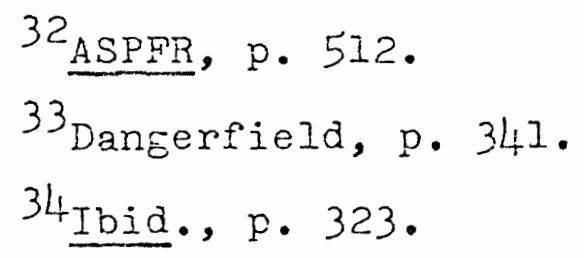


this issue of American claims is described by Dangerfield:

Livingston continued to show a singular

fertility in arguments and schemes for settling

the claims: but, as time went on, he regarded

them more and more as a form of pressure, a way

of making himself felt when he addressed himself

to the far greater problem presented by the

$\rightarrow$ retrocession of Louisiana. 35

The claims issue was pressed until the Louisiana

Purchase was completed. In April 1803 Livingston's adamancy alienated James Monroe when he assumed his post as Minister Plenipotentiary and Envoy Extraordinary. The claims issue was resolved in the Claims Convention of 1803 but livingston's argumentative intercourse with claims commission members and his support for Americans possessing questionable claims damaged the American minister's reputation. 36

On February 20, 1802 Livingston wrote to Talleyrand to inquire again whether a financial arrangement concerning the Floridas could be drawn up between France and the U. S. The agreement would aid French operations while removing triture causes of discontent between France and the U. S. since the Floridas and New Orleans constituted a part of America's strong natural boundary. 37

The supposed irony that Livingston was willing to provide France with revenue which would be allotted toward Leclerc's

$$
\begin{aligned}
& 35 \text { Dangerfield, p. } 324 . \\
& 36 \text { Ibid., p. } 387 . \\
& 37 \text { ASPFR, p. } 514 .
\end{aligned}
$$


military expedition in Santo Domingo disappears when the feedback Livingston acquired from French officials and Rufus $\mathrm{king}$ is examined. In a letter dated February 26, 1802, to Madison, Livingston pointed out that the establishment of an empire in the vest was unacceptable to every French statesman since too many men and too much money were required to effect a policy inimical to the United States and o ${ }^{2}$ no advantage to France. The committment, then, was superficial on the part of many. However, since the dream of a western empire was Napoleon Bonaparte's, the grandiose scheme was supported. 38

From Rufus King, Livingston learned that Leclerc was having many difficulties securing Santo Domingo. The British Foreign Secretary, Lord Hawhesbury, had suggested to King that if Leclerc's army were destroyed, and Hawkesbury thought this likely, a successive expedition would fail also. For this reason Iivirige ion rossessed fewer qualms about offering money to France which would in all likelinood be allocated toward outiztting and sustaining a new, and probably doomed, expedition to Santo Domingo. 39

Even as late as May 1802, six months after Livingston's arrival in Paris, Talleyrand refused to bargain and "turned into a sphinx at the mention of Louisiana. 40 Up to September

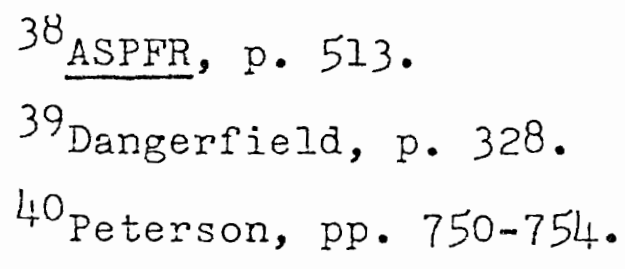


1802 Talleyrand was generally uncommunicative.

With Talleyrand eliminated as a useful source of information and a viable negotiating force, Livingston turned to his friend of many years, Barbé-Marbois: Marbois and Livingston had known each other in Fhiladelphia during the American Revolution. It was for Marbois's personal instruction that Thomas Jefferson had written his Notes on Virginia published in 1785.41 In 1/05 Marbois was assigned to the French legation in Philadelphia from whence Louis XVI appointed him Intendant to Santo Domingo. Imprisoned in 1793 and later exiled to French Guiana for two years for his political views, Barbé-rirbois in 1800 was appointed Minister of the Treasury by Napoleon. He assisted Napoleon with French finances. and interpreted for the First. Consul Toussant. I'Ouverture's behavior in santo Domingo. 42 In the final negotiations of the Louisiana Purchase, Marbois replaced Talleyrand. However in December 1801 Marbois was evasive and Livingston wrote to Madison on December. 31:

Marbois told me yesterday it was considered important to have an outlet for their turbulent spirits; yet would not explicitly achnowledge that the business had been concluded. 43

$$
\begin{aligned}
& 4{ }^{2} \text { Spraglie, p. } 281 . \\
& 42_{\text {Ibid., p. } 281 .} \\
& 43_{\text {ASPFR, p. } 513 .}
\end{aligned}
$$


Not only would Marbois receive the responsibility to conduct the final negotiations but in April 1803 his advice to Napoleon reflects a change in opinion as he encouraged the cession of Louisiana to the T. S. Louisiana's importance to France had become negligible.

Besides Talleyrand and Marbois, Livingston sought to ingratiate himself with Napoleon Bonparte. Aware of Bonaparte's aversion to democrats, Livingston assumed the role of an aristocrat. 'He refurbished the rue Tournon legation to provide a regal sumptuousness. Under the tutelage of Marbois and Pierre du Pont, the American minister attended balls, banquets and salons where politicians close to Bonaparte were likely to be present. The purchase of a cocked hat and a winged collar made Livingston's attire appropriate for a wolf hunt organized by Napoleon's brother, Joseph Boraparte. 44

To curry Napoleon's favor, Livingston, when he heard that General Leclerc's wife, Pauline, was suffering greatly from the humidity in Santo Domingo, offered his brother Edward's townhouse in New York or another in Clermont for Pauline Leclerc's use. Brother Edward Livingston was the mayor of New York City and Pauline's refusal may have preserved the propriety of these New York Livingstons since ${ }^{44}$ sprague, p. 283 
she was whispered to be the mistress of a number of celebrities, including Napoleon! 45

For 211 his efforts Livingston's behavior did not radically alter the negotiations and was of secondary importance compared to America's threatoned alliance with Britain, Leclerc's successes and failures in Santo Domingo, and the French need for revenue.

Wnile Iivingston tried to placate Napoleon, approach Talleyrand, and learn the nature and extent of the cession, he also received the help of one Dupont de Nemours. Dupont, who had come to the U. S. in 1799 and was a personal rriend of Thomas Jefferson's, was returning to France in April 1802 . Before leaving the U. S., Duport offerea his services to Jefferson on the subject of Louisiana since he was eager for a settlement mutually advantageous to France and the U. S.46 Dupont was entrusted with the important letter of April 18, 1802 in which the President responded to the rumor that Spain had ceded Iouisiana to France. His belief that such a transaction made France a "natural and habitual enemy" to the U. S. and provided cause for an Anglo-American alliance shocked Dupont. 47 The points unuerscored by Jefferson for Dupont's benefit were: the cession of New Orleans and the Floridas was "palliative" only; repossession of Louisiena

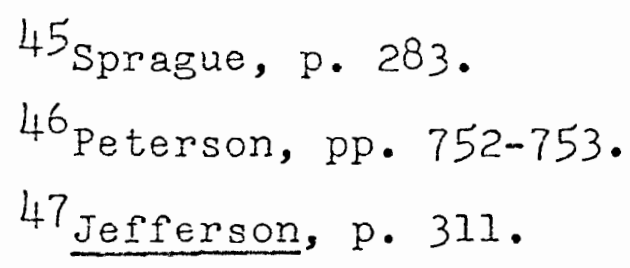


wolid destroy French sea fower and consequently appropriate all of frevica to Britain and the U. S.; and the New world was no longer a plaything to be used for Furope's recreatioral pasttirnes. mhe stunned Dupnot recommended that the U. S. offer to purchase New Oriesns and the Floridas with sold but limit her derands to the left side of the Mississippi. 48 Iefferson hoped Dupont would impress on the French Eovernment the "inevitable consequences" of possessing Louisiara. Stating that he highly ralued "a state of friendship between France and us" and he desired peace, Jefferson explained the explosive nature of this seemingly insignificant event:

In Europe, noting but Europe is seen, or supposed to have any right in the affairs of rations; but this little event, of France's possession herself of Louisiana, which is thrown in as nothing, as a mere make-height in the general settlement of accounts,--this speck which now appears as an almost invisibie point in the horizon, is the embryo of a tornado which vili burst on the countries on both sides of the Atlantic, and involye in its effects their nichest destinies. 49

Although extremely useful in Prance, Dupont was unable to rediate successfully there. He obtaired an audience with Napoleon, commicated with Talleyrand and motained the hopes of Jefferson and Madison for a necotiated settlement while

$$
\begin{aligned}
& 43^{3} \text { peterson, pp. } 753-754 \text {. } \\
& 49 \text { Jefferson, pp. } 317-318 .
\end{aligned}
$$


Livingston became increasingly impatient. 50 Even with Monroe's appointment in early 1803, Jefferson sought to retain Dupont's assistance in representing America's position. 51 Jefferson had shared his secret request to Dupont only with Madison. When the Secretary of State referred to the President's letters to Dupont in his instructions to Nonroe, Thomas Jefferson objected:

As that correspondence will make no part of the public record, perhaps it is as well it should not be spoken of in them. 52

On November 1, 1803 Jefferson wrote personally to Dupont thanking him for his assistance. 53 His efforts had been in vain; he had expended much energy in a situation demanding industry and diplomacy. Dupont's voice did not by itself bring about the Louisiana Purchase but served to vocalize an alternative which France elected when the dreams of a western empire collapsed.

Up to April 1802 neither Dupont nor Livingston were so effective as to force the French to alter their foreign policy. An absence of precise and frequentinstructions and the unwillingness of French and Spanish officials to admit

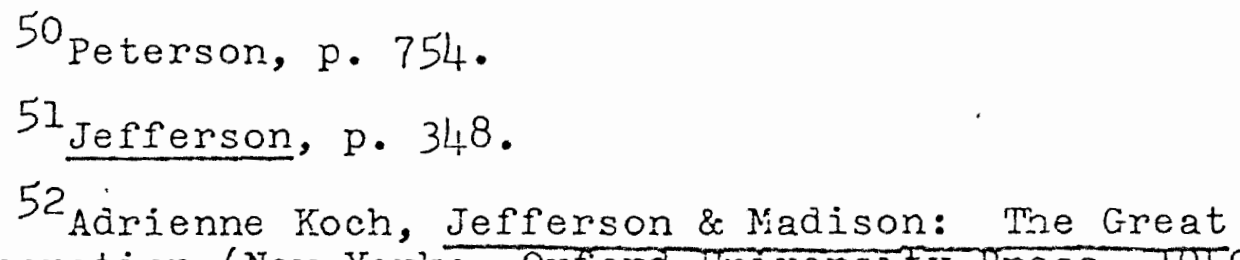
Collaboration (New York: Oxford University Press, 1950), p. 237. 53 Jefferson, p. 422. 
the cession hampered Iivingston's diplomacy.

Despite these setbacks, Robert Livingston renewed

$I$ his negotiating efforts. He employed novel techniques, took advantage of every situation and forcefully represented American concerns and interests to French officials. This persistence demonstrated American opposition to French foreign policy and her willingness to agree to some monetary arrangement which preserved American interests and allowed American expansion westward. 


\section{CHAPTER V}

\section{THE FNERGETIC IIVINGSTON}

Between May 1802 and February 1803 Robert Livingston attempted to overcome the handicaps of insufficient instructions and troublesome relations with French officials by various means: publication of a memorial in August 1802, an Eppeal to Joseph Bonaparte, and correspondence with Pufus King. These activities, plus events in Santo Domingo and Nien Orleans, contributed to Livingston's loss of status and necessitated the joint appointment of James lonroe as. a minister to France.

In March-1802 Madison received a letter from Livingston who described prevailing Frencin attitudes and ideas concerning Iouisiana. The French considered the area the most fertile in the world with New Orleans so strategically located that she commanded the trade of America's entire western country. The Indians were depicted as Francophiles especially by one Frenchman, Francis Tatergem, who considered himself very influential with the creek nations of the South. Although Livingston considered him a mere adventurer, the First Consul believed Tatergem's estimates that an amy of twenty thousand Creek warriors, filled with hatred for Amesicans, could 
easily be raised. I The Creek Indians would contribute to the fulfillment of Napoleon's dream. Livingston wrote:

It is a darling object with the First Consul, who sees in it a mean to gratify his friends, and to dispose of his armies. 2

Wile Napoleon was musing over the possibility of recruiting the Creek Indians, France and Spain were still negotiating over the Floridas. France believed the cession included the Floridas and wanted Spain to reverse her interpretation of the cession which excluded them. With the situation in flux, Iivingston had tried to secure instructions from Washington D. C. but none were received. In his letter to Madison on May 28, 1802 Livingston asserted that if he failed to hear from the secretary of state or the President soon he would present a memorial to France. ${ }^{3}$ The American diplomat wrote:

I wait impatiently some further instructions from you; those I have, in some sort prohibiting such measures as may show any dissatisfaction on the subject, of which, however, I doubt the policy. The subject is so interesting as to induce us to risk something to defeat it. 4

Apparently no instruction prohibiting the memorial arrived to prevent its publication. During the summer

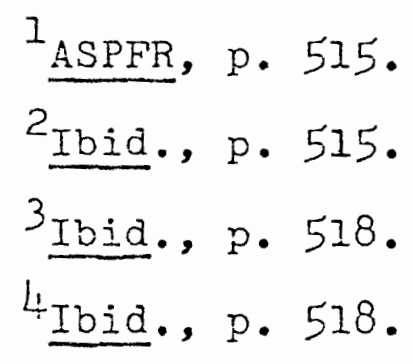


Livingston prepared the memorial, made twenty copies and distributed them among Napoleon's advisers. 5 In the memorial he addressed himseli to the status of the Floridas and problems resulting from a French colonization of Louisiana.

Livingston proposed that the United States purchase the Floridas. Referring to the negotiations underway between Spain and France the American minister concluded:

I speak in all this business as if the affair of the Ploridas was arranged with Spain; which I believe is not yet the case. 6

Livingston apparently believed France might one day possess the Floridas since his memorial sought to discourage French colonization of not only the Floridas but of Louisiana. He argued that France's population was too small to require colonization. and available. French capital was insuficicient for colonial investment. Since "transmarine colonies add nothing to the strength of a ration," it was to France's benefit to invest her capital in home manufactures. At present French possessions in the West Indies and Cayenne were more than sufficient to satisfy French and European demands. With western expansion these French colonies would need to be made more productive thereby creating another demand on French capital. 7

$$
\begin{aligned}
& 5 \text { ASPFR, p. } 520 . \\
& 6_{\text {Ibid. }}, p \cdot 520 . \\
& 7_{\text {Ibid., p. } 520 .}
\end{aligned}
$$


In addition to the problem of insufficient capital, Louisiana's climate required slave labor. These slaves would need to be fed, clothed and maintained for many years before their work was profitable. The profit would be in greater peril since such slaves, living near the wild forests and natives of North America, would frequently escape. 8 Even if France deciced to invest her capital in Louisiana, the investment would not yield quick returns and would be unstable due to the unreliable work force.

To colonize Louisiana would not be profitable to France or the West Indies. If France introduced her products into Louisiana, she would only reduce tre price of items imported from the islands and would, Iivingston insisted, find herself destroying these products since quantity decreases value. A greater expense would befall France if she chose to grow in Louisiana those crops, such as rice, which were profitably being raised on the islands. At the present the West Indies secured lumber from the Northern States and paid with molasses and a West Indian rum called "tafia". This trade was inexpensive to the island planters. If the planters were forced to buy wood from Louisiana, their costs would increase and the market for rum and molasses would end since these are consumed only in the Northern States. The

$$
8 \text { ASPFR, p. } 521 .
$$


existing balance of trade would be destroyed. ${ }^{9}$

Livingston responded to the argument that Louisiana offered additional markets to French manufacturers by asserting that the French emigrant to Louisiana wolld consume less in the New World than he nad in the 0Id. The consumption of manufacturing goods among the slaves would be smaller yet. Inhaoitants already living in Louisiana make many of their own products or rely upon Britain for necessary articles. Therefore French manufacturers would find it difficult to introduce their products since the demand for their goods does not exist. Not only would such products be difficult to introduce, but travel through the Gulf into the mouth of the Mississippi and upriver was dangerous, slow and expensive. overland transportation of goods through canals and on roads was faster and cheaper and these two factors provided American and British goods with advantages over French products. ${ }^{10}$ Finally, the American minister addressed himself to the consequences of a French occupation of New Orleans. Since one-third of the mercantile houses in New Orleans were owned by U. S. citizens, these houses would be removed if a French military government were established there. American merchants would relocate to a site in agreement with the terms of the Pinckney Treaty or to Natchez which would become a free port

$$
\begin{aligned}
& { }^{9} \text { ASYFK, pD. 521-522. } \\
& { }_{10 \text { IDid., p. } 523 .}
\end{aligned}
$$


receiving any vessel that could enter New Orleans. 11

Atter declaring that France possessed insufficient capital, that French development of Louisiana would be disruptive to French possessions, and that French manufacturers would obtain no profits by attempting to sell their products in Louisiana, Livingston then contradicted himself when describing the economic success France could achieve in Louisiana if she agreed to cede New Orleans to the U. S. Then, by using the Mississippi River to transport her products, French commodities could be successfully introduced when the irhabitants developed a preference for them over British goods. These French goods would need to be cheaper. This would be accomplished by interesting American merchants in the sale of these proaucts, by employing the capital of American merchants, and by altering the American consumers' preference for British goods. ${ }^{12}$ suddenly traveling upriver on the Mississippi was commercially profitable, the hazards and slow progress were immediately overcome and forgotten and the intractable tastes of the inhabitants were easily changed.

The memorial was circulated languidy among Bonaparte's advisers. 13 Despite this dissertation and other proposals,

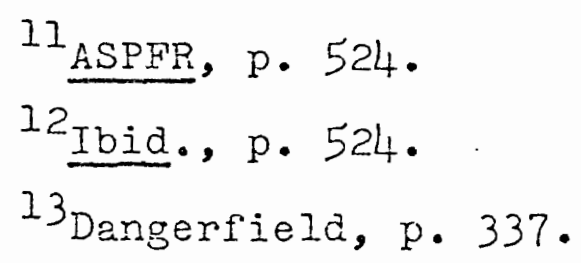


they informed livingston that every offer vas premature and the French government remained determined to take possession of Louisiana. The fulfillment of Napoleon's dream of a western empire was neerer with Leclerc's military successes and, therefore, the impact of the memorial was not as great as the American minister had hoped. Livingston expressed his frustration in his letter of september 1,. 1802 to Nadison:

There never was a Government in which less could be done by negotiation than rere. There is no people, no legislature, no counseliors. One man is everything. He seldom asts advice, and never hears it unashed. His ministers are mere cleris; and his Iegislature and Counsellors parade officers. 14

Following tre distribution of his memorial, livingston received a letter from thomas Jefferson who encouraged him not to be impetuous in his relations with French officials. Jefferson recommended that all communications with the French should be of a "mild, complaisant, and even friendly complexion, but always independent." 15 Jefferson continued:

Ask no favors, leave small and irritating things to be conducted by the individuals interested in them, interfere ourselves but in the greatest cases, and then not push them to irritation. No matter at present existing between them and us is important enough to risk a breach of peace; peace being indeed the most important of all things for us, except the preserving an erect and independent attitude.

Although I know your own judgment leads you to pursue this line identically yet I thought it just

$$
\begin{aligned}
& 14 \text { ASPFR, p: } 525 . \\
& 15 \text { Jefferson, pp. } 335-336 \text {. }
\end{aligned}
$$



to siribengthen it by the concurrence of my
own.

Perhaps word of Livingston's frustration had been relayed to Jefferson or Madison who interpreted the memorial as aggressive diplomacy and evidence of Iivingston's impatience.

Befors this letier reached Livingston, the frustrated American diplomat, realizirig that his negotiating efforts were being seriously impeded by Talleyrand, was trying to discover another person with whom business could be conducted. On October 26, 1802 Livingston enjoyed an interesting conversation with Joseph Bonaparte who expressed his willingness to receive any unsigned and informal communications. 27 Joseph Bonaparte was described by George Dangerfield as:

... a lazy and somewhat hypocritical personage, who had, none the less, the ear of his brother, ang who was ready to intermeddle-in affairs of-State.

Saving secured the attention of Napoleon's brother, Livingston attempted to learn how much Joseph knew about the f?known and possibly changing, status of the floriaas by inquil his whether all obstacles might not be overcome if Hrance returned Louisiana to Spain but retained New Orleans. New Orleans could then be added to the Floridas and ceded to the United States in return for the assumption by the U.S. of American claims against France. Joseph Bonaparte failed

$$
\begin{aligned}
& 16 \text { Jefferson, pp. } 335-336 . \\
& 17_{\text {Dangerfield, p. } 339 .} \\
& 18_{\text {Ibid., p. } 338 .}
\end{aligned}
$$


to reply but asked Livingston if Americans preferred the Floridas over Louisiana. Livingston responded affirmatively. 19 By November 1802 'l'alleyrand disclosed to the omnipresent Livingston that the provisions of the Pinckney Treaty would be respected by the French. Livingston was dubious. The status of the Floridas was finally disclosed as not included in the cession; affairs in Europe grew more unstable and the Peace of Amiens became shaky. 20 France was still negotiating for the Floridas and offered to sell Parma to Spain for $4,8,000,000$ livres $(\$ 18,240,000)$ or exchange Parma for the Floridas. Livingston concluded in a letter dated November I4, 1802: to Madison:

You see by this the value they put on Florida

I fear Spain will accede to their proposition. 21

From December 1 to December 24, 1602 Livingston initiated a new series of negotiations which combined fantasy with statesmanship. Approaching Joseph Bonaparte first, Livingston presented his unique proposal. Believing it reasorable to assume that Napoleon Bonaparte would be raised to a higher rank, with his new imperial title becoming a hereditary one, and recognizing that national ingratitude and domestic

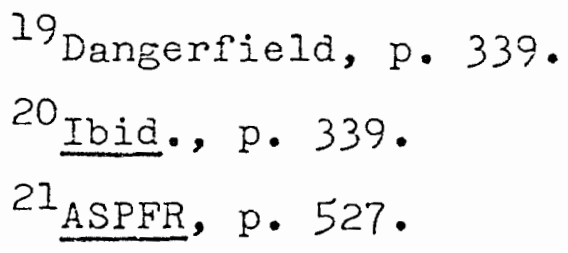


convulsions were counterparts of politics, Bonaparte's family might some day require a haven. Therefore, a permanent establishment for the first Consul's family could be the land including New orleans and the strip of province lying east of the Mississippi including West Florida. The First Consul's family would own the land but the territory would be under the jurisdiction of the United States. In return for receiving jurisdictional rights, the U. S. would grant France certain commercial advantages such as placing the French trade at New Orleans on an equal standing with American trade. If agreeable to the First Consul, Livingston, without possessing the proper authority to do so, offered to pay $\$ 2,000,000$ either in money or J. S. stock paying 6\% interest.for New Orleans and West Florida. 22

Joseph Bonaparte rejected Livingston's rationale since it affected the Bonaparte family, but agreed to send to Napoleon a postscript proposing the cession of New Orleans and West Florida as far east as the Perdido River to the United States. To compensate France for the loss of New Orleans, a French port could be constructed at Leon directly opposite New orleans. In the cession would also be an area lying west of the Mississippi River and above the mouth of the Arkansas River. The ceded territory west of the River would calm

$$
22 \text { Dangerfield, p. } 341 .
$$


American apprehensions by preventing an alliance in North America between Great Britain and France. 23

The next note Livingston wrote Joseph Bonaparte contained no references to a familial haven but repeated the proposal of a French cession of New Orleans, West Florida and the land above the mouth of the Arkansas River to the U. S. New Orleans was described as being of little advantage to the French since the area possessed a naked bank, no port, basin or quay for shipping and no strong fortifications. If war broke out, Great Britain could easily seize West Florida and Louisiana, add them to her possessions, and with her powerful navy proceed to "annihilate the external trade of every other nation in Europe." This fate could be avoided if France made the cession to the U. S., fortified Pensacola and Tampa, or left them under Spanish control. The wisest decision France could make would be to not only include West Florida in the cession but to pledge, without delivery of title or possession, East Florida for a certain number of years in order to satisfy a portion of the American claims. 24

Livingston, believing these letters would alter Napoleon's position revealed his enthusiasm in a dispatch

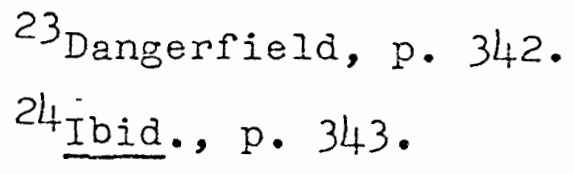


to Madison:

I have, in a private memoir under the Consul's eye, touched a string that has alarmed them. I cannot now explain. The minister knows nothing of this... It is an important card in my hands, and must, for tre present at least, be somewhat under my control. 25

Livingston was hopeful until January 7, 1803 when Joseph Bonaparte informed him that in the future he must address himself to Talleyrand. 26 The new series of regotiations halted as Livingston was forced once more to appeal to the uncooperative Talleyrand. When in early Januarj, Iivingston heard that the right of deposit at New Orleans had been revoled, he wrote immediately to the French minister and decried the closure as an unfortunate circumstance cocurring at the moment when France was planning to possess Louisiana. The Freneh-silence as to her intentions in Louisiana, " Iivingston wrote, "will (I very much fear) give room to jealous and suspicious persons to suppose that the court of Spain has, in this instance, acted in concurrence with that of France." Livingston then suggested a way for France to remove herself from this difficulty. Knowing that France did

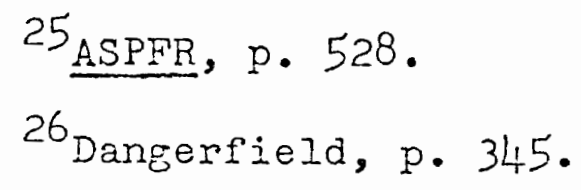


not possess the Floridas, Livingston stressed that Louisiana, without the Floridas, was worthless. 27

France could cede to the U. S. that part of Louisiana lying above the mouth of the Arkansas River and thereby establish a buffer area between French possessions and Canada. France would retain the area west of the Mississippi and south of the Arkansas River as a barrier between the U. S. and Mexico. France would own East Florida as far east as the Perdido River with the U. S. acquiring West Florida, New Orleans and the territory on the left bank of the Mississippi. As for New Orleans, Livingston threatened that the U. S. could easily develop Leon if the French retained New Orleans. Leon would receive the capital now invested in New Orleans and New Orlean's value to France would be destroyed. 28 In closing, Livingston suggested that should France not take advantage of ceding certain territories to the American States, the U. S. might still be forced to make an allianee with Britain. England was increasing in power since her recent looting of India had given her much capital which, invested in an industrial revolution, woula make her ultimately victorious over Napoleon. To give credence to this threat of alliance, Livingston made marked diplomatic

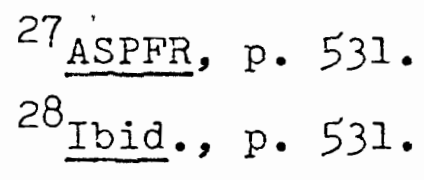


advances to Lord Whitworth, the British Ambassador in France. ${ }^{29}$

Talleyrand's responses were not encouraging. Livingston was faced with the diplomatic barriers hel had encountered so frequently in the past. These barriers and Livingston's subsequent impatience had compelled him to turn to Rufus King, hoping that through him sympathy for American demands could be aroused at Whitehall. 30 As early as December 30, 180I, Livingston was corresponding with King and relating to him the possible consequences of the rumored cession of Louisiana from Spain to France. Livingston hoped to strike a responsive chord by pointing out that with French expansion into the New World, not only would English possessions be endangered but Britain as well. Therefore, the English would do well by trying to prevent a final settlement-of the cession. 31 King's reply was written seventeen days later. He had tried to impress a number of English leaders with the consequences of the cession but Britain, desiring peace, would not interfere. Although England would demonstrate "no open measure of opposition," since trat "would afford a Pretence to involve her in new difficulties," she would throw impediments in the way of its completion. 32

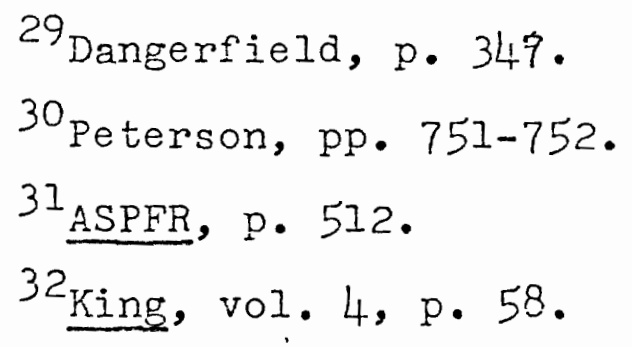


King encouraged Livingston to reveal what grievances the U. S. would suffer if the cession were completed aid to explain the American hope to live in harmony with France. 33 Fearing that his suggestions might offend Livingston, King apologized:

But I have to entreat your Pardon for any sugsestions on my part upon Subjects which your superior Judgment and experience are much more capable than mine to conduct. 34

In March 1802 Iivingston was still encouraging British participation at Amiers. This time he referred to the potential problems of an unsettled bounäary between Canada and Louisiana if the French acquired Iouisiana. 35

This correspondence between King and Livingston drew the attention of the President and the secretary of state. radison's brusque letter of March 16, 1802 reacted to the poor judgment used by Livingston in his letter of December 30 , 1801 to Rufus King, and clearly admonished both of them:

The subject of your letter to Mr. King, of the 30 th of December, is regarded by the Presiaent as not less delicate than you have supposed. Considering the particular views which Great Britain may mingle with ours, and the canger that a confidential resort to her may be abused, for the purpose of sowing jealousies in France, and thereby thwart our

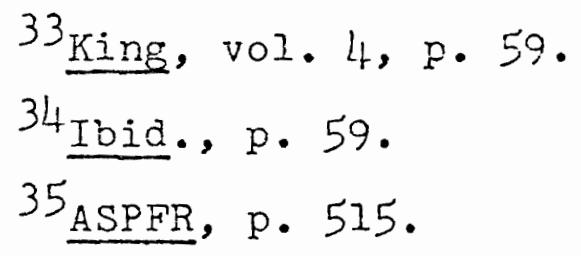


object, you and Mr. King will both be sensible

that too much circumspection cannot be employed. 36

Neanwhile, King continued the correspondence with

Iivingston. Although the American government had not sent instructions concerning the cession to King, he had formulated opinions which he freely shared with his diplomatic cohort in France. 37 On March 23, 1802 King again informed Livingston that Great Britain would not assist the U. S. in matters regarding the cession; America was to be self-reliant. King suggested that the U. S. might acquire legitimate title to Louisiana and the Floridas with a large sum of money since the U. S. had nothing else:

No set of claims; no balancing of accounts; no prospect of future disadvantage will have any beneficial influence in our favour. 38

However, even if it were possible to extend the American frontier to the Pacific Ocean, this would impose burdens on the American people. The plan, then, would be ill received. King, therefore, believed it preferable to secure only New Orleans and the Floridas but to do so only through diplomatic means, not military. 39 By frankly declaring America's intent to assert her rights and interests and by outlining the possible

36 ASPFR, p. 514 .

37 King, vol. 4, p. 89. 3,8 Ibid., p. 87 . 39 Ibid., p. 87. 
consequences to France if the U. S. failed to acquire New Orleans and the Floridas, the United States might be $\checkmark$ successful. 40 King concluded with an idea foreshadowing the Monroe Doctrine of 1823:

The Truth should not be disguised from ourselves or others; that we are the tiirst Power in our own hemisphere, and that we are disinclined to perform the part of the second. 4

In a letter dated JuIy 12, 1802 to Livingston, Kirg continued to examine the subject of the cession and concluded thai tne $\bar{u}$. S. should not explicitly sanction it. If Louisiana and the Floridas remained with Spain they would shortly imitate the American colonies and become independent. If the probable war between frrance and kingland resumed and Spain aligned herself with France, then England would most likely succeed in taking possession of New Orleans and the Floridas. England would then cede them to the U.S. Therefore, King advised Livingston to refrain from forming any cumbersome guarantees with France or any other power for the purpose 01 securing New Orleans and the Floridas since these areas were bound to be free in the near future. 42

$$
\begin{aligned}
& 40_{\text {Iing, }} \text { vol. } 4, \mathrm{p} \cdot 89 . \\
& 4 \text { Ibid. }_{\text {Ib. }} .89 . \\
& 42_{\text {Ibid., pp. } 146-147}
\end{aligned}
$$


This correspondence continued and before departing for the United States, Rufus King traveled on the Continent and consulted witn Livingston in Paris. 43 Although the British had not cooperated by creating impediments at Amiens, Livingston had appreciated King's correspondence. King, the Federalist, and Livingston, the Republican, were able to put aside partisan differences and combine their intellectual energies to respond to a problem averse to American interests.

While Livingston was publishing his memorial, conferring with French officials, and corresponding with Rufus King, he was careful to verify any rumors concerning expeditions to Louisiana. Prior to Apriz 1802 Livingston had informed Madison of an expedition under General Victor which reportedly had been oraered to. Louisiana.... Originally. Iivingston had been alarmed but in April he minimized the danger. In late Nay, Livingston wrote Madison that the expedition had been delayed until september. 44 Again Livingston was relatively unconcerned since he was certain that France would finally relinguish Louisiana and cede New Orleans to the U. S. 45

Americans eagerly and anxiously followed General Leclerc's successes and setbacks in Santo Doningo. Believing that

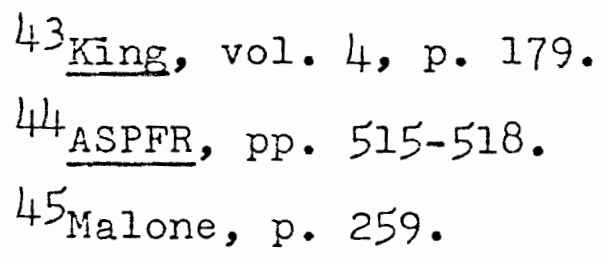


Leclerc's work on Santo Domingo would not be accomplished quickly, Livingston must have been surprised at the news of Leclerc's capture of Toussaint L'Ouverture in 1802. This news did not trigger the departure of Victor's expedition from Dunkerque on the Straits of Dover since Charles IV of Spain had not yet ordered Louisiana delivered to France. The issuance of the order to deliver on October 15, 1802, made the French occupation of Louisiana credible. 46 However, Livingston on November 11, 1802, told Nadison that orders for the embarkation of Victor's troops had encountered some diplomatic difficulty regarding the provinces of Parma and Placentia and the expedition was now preparing to sail from Holland in approximately twenty days. 47 Hore impediments to the embarkation followed.

Affairs in Santo Domingo had changed. General Leclerc's successes were reversed and the French soldiers confronted disaster. Napoleon tried to put off informing the French people of events in Santo Domingo but on January 7, 1803 he was finally obliged to publish the account of Leclerc's death and virtual destruction of his army of 30,000 men from the fever. It was impossible for General Victor to relieve the remainder of Leclerc's army or to retain French control

$$
\begin{aligned}
& 46_{\text {Malone, p. } 259 .} \\
& 47_{\text {ASPFR, p. } 526 .}
\end{aligned}
$$


of the island since his expedition was icebound in Helvoet Sluys in Folland. 48 Napoleon's dreams for a western empire were quichly crumbling and yet he persisted to press Spain for the Floridas as if they could be of value although France colid not even maintain a stronghold on Santo Domingo, the gateway to Louisiana.

While French soldiers were dying painfully in santo Domingo and Napoleon was impatiently noting their lack of progress, the Spanish Intendant of New Orleans on October 16 , 1802 revoked Americans' right of deposit. 49 Ironically on that same day a letter arrived from Dupont de Nemours to Jefferson revealing that the price of six million dollars had been named for New Orleans and the Floridas on the condition that France received the same commercial rights as the U.S.50 What was even more ironic was that the French were ready and willing to sell land that spain claimed France did not possess.

The closure of New Orleans sparked an immediate crisis whose consequences would soon be felt at the cession negotiations in France. Through NEw Orleans from Kentucky, Tennessee, Mississippi, Ohio and the Indian territories passed produce

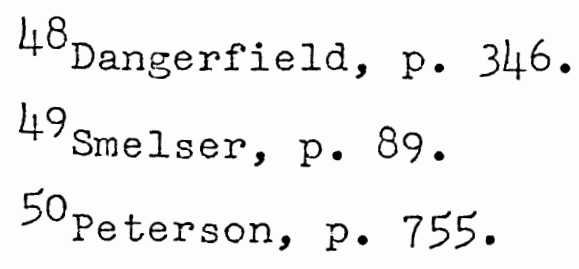


I estimated at $\$ 3,000,000$ annually. Another million dollars in produce came from $S t$. Louis and the Spanish villages Ste. Genevieve, Arkansas Post, Natchitoches, etc. 51 In July the Spanish Intendant, Juan Ventura Morales, acquired permission from Spain's Charles IV to close the depot if Morales ever thought it wise. In the spring of 1802 many American shippers began to use the deposit privilege as a cover fortine smuggling of Spanish gold and silver. When Morales asked the shippers to halt the smuggling, they rejected his authority by informing him that New Orleans was no Ionger Spanish but French. On October 16, I802 Morales posted the notice of the suspension of the right of deposit. On October 15 Charles IV had officially conveyed Louisiana to France. 52 .

The reaction was immediate. On October 18,1802 Governor Claiborne asked James Madison whether another place of deposit on the banks of the Mississippi had been assigned by Charles IV since such information could not be ascertained from the Intendant's proclamation. It was subsequently learned that in violation of the Pinckney Treaty with Spain another location had not been appointed for deposit. 53

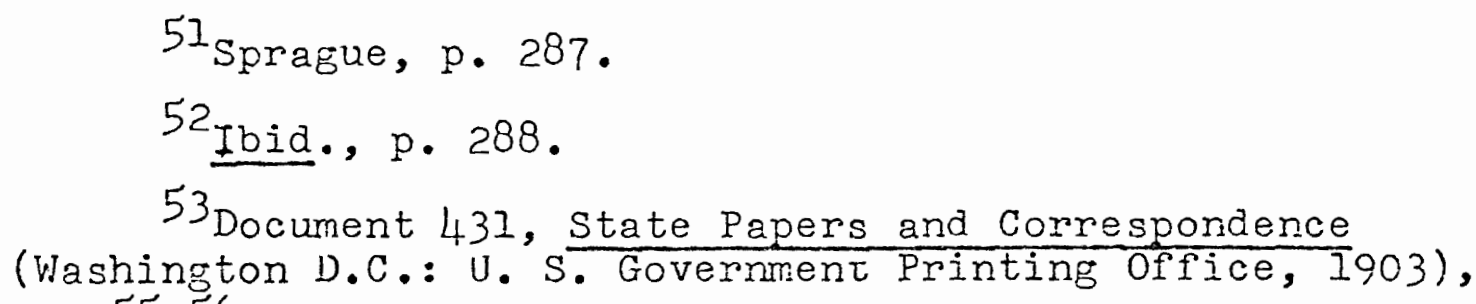


According to Governor Claiborne the impact of the closure was extensive:

It has inflicted a severe wound on the agricultural and commercial interests of this Territory, and will prove no. Iess injurious to all the Western country. 54

The Proclamation did not deny Americans the right to navigate the Mississippi, but Madison wrote to Charles Pinckney on November 27, 1802 the following:

It is evident that the useful navigation of the Mississippi so essentially depends on a suitable depository for the articles of commerce that a privation of the latter is equivalent to a privation of both." 55

Americans believed the appointment of a substitute depot was an incontestable right. Not only were the farmers along the Mississippi at the mercy of Spain but so were those along the Mobile and Apalachicola Rivers in west Florida. 56 The beneficence of Spain was subservient to her mercantilism. A Congressional committee concluded that Spain had the following intentions:

To engross to itself the trade of its colonies, and affords us every reason to apprehend that Spain will not readily admit us to pass through her territory to carry on a trade either with each other or with foreign nations. 57

$$
\begin{aligned}
& 54 \text { State Papers and Correspondence, p. } 55 \\
& 55 \text { ASPER, p. } 527 \text {. } \\
& 56 \text { State Papers and Correspondence, p. } 86 . \\
& 57 \text { Ibid., p. } 86 .
\end{aligned}
$$


This Congressional committee confirmed the calamitous effects the closure had on western lands even if Americans retained the right to navigate the Mississippi River. An outlet to the sea was necessary to maintain trade with foreign markets and the Atlantic States. The committee, despite the militaristic response of westerners and Federalists, proposed an appropriation of $\$ 2,000,000$ to secure the right of deposit peaceably by purchasing New Orleans and the Floridas. 58 Congress agreed: to the appropriation. 59 While Jefierson attempled to forestall martial Federalists, the Spanish minister to the United States, Marques de Casa Yrujo, was easily induced to denounce publicly the cessation of the American right of deposit at New Orleans. 60 This inaicates that the revocation was not a concerted action promoted by Spanish officials. Apparently Intendant Morales was acting alone, relying on the permission he had previously secured from Charles IV and concealing his plans from everyone including Spanish officials of higher rank than he. 61

Events in Paris moved quiclily during the first four months of 1803. On January 3, 1803 Livingston learned of

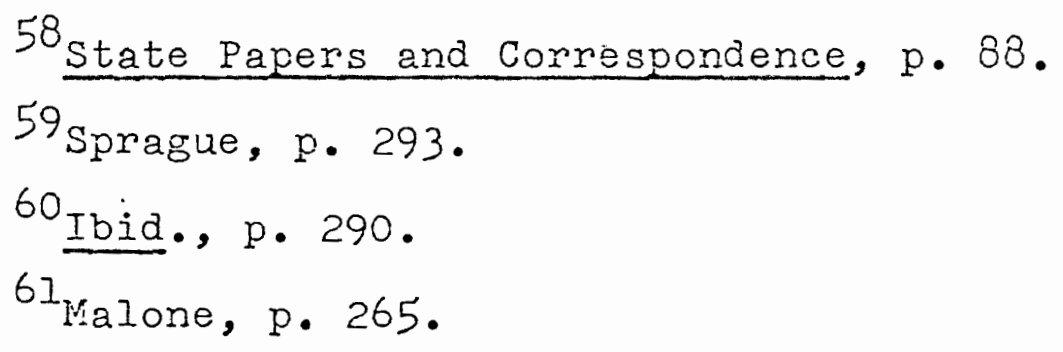


the closure of New orleans. 62 While Victor's expedition remained icebound in Holland, Livingston pressed American interests by pursuing negotiations with Talleyrand. Their diplomatic relationship failed to improve and livingston blamed the slow pace of the negotiations on Madison. In a letter written in mid-February the American minister asserted that he could arrange a conference with Talleyrand anytime but was only postponing the appointment until specific instructions from Madison had been received. 63

Although they were not meeting, Livingston and Talleyrand were corresponding with one another. In his letter of February 19, 1803, Talleyrand denied Livingston's charges that French finances were in a state of embarrassment. 64 Livingston continued to deal jointly with the issues of Louisiana and the American claims and he estimated the total of those claims at 20,000,000 livres or $\$ 7,600,000$. Talleyrand's response to the claims estimate was as follows:

It is entirely new to us that they Ithe claims 7 can be raised, by any veluation whatever, to the sum of twenty milizons. 65

Talleyrand upbraided the American minister for linking together the two disparate matters:

$$
\begin{aligned}
& 62 \text { Dangerfield, p. } 344 . \\
& 63 \text { ASPFR, pp. } 532-533 . \\
& 64 \text { Ibid., p. } 546 . \\
& 65 \text { Ibid., p. } 546 .
\end{aligned}
$$


Affairs so different in their nature ought to be kept as mucin as possible apart, and should certainly not be united. It is entirely opposed to the maxims of Government, adopted by the republic, to mingle important and delicate political relations with calculations of account and mere pecuniary interests.

Almost two weeks later the French Minister was still criticizing Iivingston's mingling of diplomacy and finance. At the same time Livingsion was informed of the appointment of General Bernadotte as French Minister to Washington D. C. His instructions were to clarify the claims issue. 67 Bernadotte's appointment nullified Livingston's need to approach Talleyrand on the subject of the American claims and even Louisiana since it was, according to Talleyrand, "the fixed determination of this Government to treaty only in America."68 In Talleyrand's

$$
\begin{aligned}
& 66 \text { ASPFR, } p \cdot 546 . \\
& 67 \text { Dangerfield, p. } 349 . \\
& 68 \text { ASPFR, p. } 545 \text {. Iivingston initially interpreted }
\end{aligned}
$$
Bernadotte's mission as a threat to successful negotiations in France. On January 24, 1803, the American minister had informed Madison of the extent of Bernadotte's powers: "He will have full powers to settle everything." By February 18 Livingston had reevaluated the appointment. He wrote to Madison: "And I believe you may look upon his present mission as honorable banishment."

Monroe in his Autobiography stated that Bernadotte's appointment was banishment more than honor since Napoleon was jealous of the General's power. Military chiefs were Napoleon's competitors. Therefore to rid himself of Bernadotte, Napoleon had offered him the Government of Louisiana but the General refused when certain of his requests were denied. Then the First Consul proffered Bernadotte the mission to the United States, granting him much "power to adjust all the differences with that rising Republic." Other inducements were added making the assignment very attractive. Bernadotte accepted, not realizing that the First Consul still intended to settle 
opinion news of Monroe's appointment further decreased Livingston's need to negotiate with him. What Livingston could do in France was try to restore America's right of deposit at New Orleans. Talleyrand concluded:

If, upon the arrival of Mr. Monroe, he can suggest anything better. I shall heartily concur with him.69

The final rebuff. Livingston's former efforts confronted an impenetrable obstacle not just in Talleyrand and Bernadotte but in Honroe's appointment.

On January 13, 1803 the United States Senate approved James Monroe's appointment as Minister Plenipotentiary and Envoy Extraordinary to France. ${ }^{70}$ His appointment allowed French officials to put off negotiations with Livingston until the new minister's arrival. While diplomatic activity between French and American ministers was at a stalemate, the French moved toward a resumption of war with England. The Peace or' Aniens Detween them appeared shaky as Napoleon publicly and ironically accused British Iord Whitworth of

the cession question in France. Bernadotte left Paris before Monroe's arrival but with the delay in the sailing of his frigate to America, he learned of the Treaty before he left France. Indignant, General Bernadotte returned to Paris. The Autobiography of James Monroe, ed. Stuart Gerry Brown (Syracuse, New York: Syracuse University Press, 1959), pp. 180-181.

$$
{ }^{69} \text { ASPFR, p. } 545 .
$$


representing a sation intent on war and belligerently responded to the Britain's protestations with "I must either have Malta or war!"7l

$\rightarrow \quad$ In the midst of these European tensions Livingston was coming to the end of his solo diplomacy. He had followed a tedious daily scheaule, conducted creative negotiations through extralegal charnels and relentlessly pursued his instructions to confirm the cession and to determine its extent. However, the memorial he had published in August 1802 had been too aggressive and unvisely alluded to a Franco-American solidarity when America's bargaining position depended partly upon her threats of alliance with England. 72 Livingston's correspondence with Rufus King had violated common sense and his proposals of a familial haven for the Bonapartes had appeared absurd to the President and Secretary of State. With their increasing doubts concerning Iivingston's judgment and with the obstacles confronting him standing as impediments to fruitful negotiations, Madison and Jefferson turned more to the French minister in the States, Pichon, who in turn passed on their concernsand requests to ranking French officials

$7 I_{\text {Henry Adams, History of the United States During the }}$ Aaministrations of Jefferson and Vadison, Vol. I, Jefferson, abridged (Englewood Cliffs, New Jersey: Prentice-Hall, $1963), \mathrm{p} .60$.

72 peterson, pp. 757-758. 
and the First Consul. Instructions were less frequent until Livingston wrote on February 18, 1803:

I am not satisfied, from examining my instructions, and commission, that I am empowered to do anything but the common routine of business.73

To restrict Livingston to a "common routine of business" were Jefferson's and Madison's intentions. The President of the United States, the secretary of state and the senate had decided that negotiations in france were to be continued through the joint efforts of Robert R. Livingston and his new associate, James Monroe. If Livingston were chagrined over the limitations imposed upon him in his instructions, then his reaction to Monroe's appointment could predictably be disappointment, embarrassment and anger. 
CHAPTER VI

THE JOINT COMMISSION AND THE LOUISIANA PURCHASE

The Seventh Congress of the United States on January II, 1803, received President Jefferson's Annual Message describing America's concern with the cession of Louisiana to France and the anger of the western territories over the suspension of the right of deposit at New Orleans. To aid in the negotiations with France, Jefferson proposed the appointment of an additional diplomat to join Livingston. This new appointee would carry with him the most recent sentiments of the public and the opinions of American officials as secured "by full communications of all the views we entertain on this interesting subject." Therefore; Livingston and Charles Pinckney were nominated to serve as ministers plenipotentiary and James Monroe as minister extraordinary and plenipotentiary in both France and Spain, since the Floridas remained Spanish possessions. ${ }^{1}$ The senate confirmed the nominations on January 13, 1803. Following the Senate's confirmation, Thomas Jefferson wrote to Monroe explaining the importance of an informed negotiator in France and notifying him of his appointment.

${ }^{1}$ ASPFR, p. 475. 
Jefferson referred to the "agitation of the public mind" generated by the closure of New Orleans. No measure had yet calmed the west and, realizing that the issue of New Orleans and the Floridas had so many facets which could only be imparted through "full and frequent oral communications," the only alternative was to send a minister extraordinary to join Iivingston. Selecting this person had been a simple matter, Jefferson conficed. The President wrote:

Having determined on this, there could not be two opinions among the republicans as to the person. Iou possessed the unlimited confidence of the administration and of the western people; and generaliy of the republicans everywhere; and vere you to refuse to go, no other man can be found who does this.?

In Jefferson's opinion, the country would experience an immediate calm if Nonroe accepted; his refusal would lead to universal chaspin. The destiny of the United States rested with this mission and only Monroe possessed tnose qualifications which enabled him to assume such a momentous responsibility. Jefferson assured Monroe:

But some men are born for the public. Nature, by fitting them for the service of the human race on a broad scale, has stamped them with the evidences of her destination and their duty.3

$$
\frac{{ }^{2} \text { Jefferson, p. } 344 .}{3 \text { Ibid., p. } 344_{4}}
$$


To Jefferson and Madison, Monroe's acceptance vas necessary since they were convinced it would appease the West, which considered the navigation of the Mississippi River and the right of deposit at New Orleans indispensable. 4 To Charles Pinckney, Madison described the importance of the Mississippi River to Westerners:

It is the Hudson, the Delaware, the Potomac, and all the navigable rivers of the Atlantic States, formed into one stream. 5

The Westerners were commercially dependent upon the Mississippi River and they were willing to accept Monroe as their spokesman in place of Livingston, whose aristocratic interests appeared inimical to theirs. 6 Monroe understood the Westerners' problems. When he had served as a Congressman from Virgina, he had sympathized with the economic needs of the West, and supported the rights of the western population

$4_{\text {New Orleans had become the depository of an increasing }}$ amount of commercial products transported down the Mississippi River and its tributaries and shipped to the Atlantic states and foreign countries. The right to deposit was indispensable since such products were floated down from the Ohio and Cumberland valleys in keel and flatboats and New Orleans was the strategic location for unloading and storing these goods before they were loaded onto ocean-going vessels. Thomas P. Abernethy, The South in the New Nation, 1789-1819, vol. 4 of A History of the South, ed. Wendell Holmes Stephenson and $E$. Merton Coulter, 10 vols. (Louisiana: Louisiana State University Press, 1961), p. 254 .

$$
\begin{aligned}
& { }^{5} \text { ASPFR, p. } 527 . \\
& { }^{6} \text { Sprague, p. } 292 .
\end{aligned}
$$


to.navigate the Mississippi. 7 He had fervently opposed the Jaj-Gardoqui Treaty of 1785, which would have postponed for twenty-five years the western navigation of the River. 8 While the Westerners appreciated his stance on domestic issues, Monroe's extensive political background qualified him for the diplomatic appointment. He had served as a Representative from Virginia in the Fourth, Fifth and Sixth Congresses and had been elected Senator from Virginia in 1790.9 Serving as Senator for three Congressional sessions, Monroe held important committee assignments, introduced a controversial bill which would have opened doors of the senate to the public, assumed the leadership of the Republican Party in the senate and promoted a policy of friendship toward France. Despite Monroe's critical comments of Federalists Alexander Hamilton and John Jay, Washington in 1794 offered Monroe the post-of. Minister to France-to-replace-Gouverneur Morris . who had been recalled at the request of the French Government. Since relations between France and the U. S. were disintegrating, Washington thought it best to appoint a Republican to the ministerial post in France. 10 In 1796 Konroe was recalled

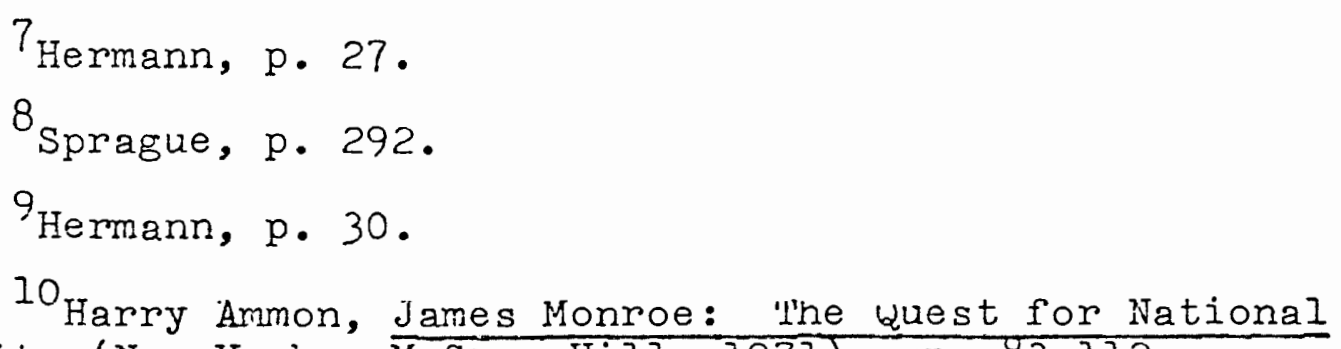
Identity (New York: McGraw-Hil1, 1971), pp. 83-112. 
from France due to his opposition to Jay's Treaty and his attempts to weld France to the United States when Washington had decided to intently pursue arniable relations with Englana. ${ }^{1}$ Monroe returned to the states and in 1799 the citizens of Virginia elected him Governor. ${ }^{12}$ When ronroe's gubernatorial term was ending early in 1803, he was planning a journey West to inspect his Kentucky landroldings before resuming his law practice. 13

When Jefferson requested his services as a minister in January 1803. Monroe's reaction was mixed. France had changed much since he was there in the 1790's. The French Directory and her Councils had been supplanted by a Consular government; democracy was no longer popular. ${ }^{14}$ There was also the possibility that this second diplomatic venture might end in failure, threatening political suicide at home. In addition to the changes in the French government and the possibility of failure, Monroe's finances would be taxed. He had been forced into debt as a result of his last diplomatic effort and had not yet fully recovered from that debt. 15

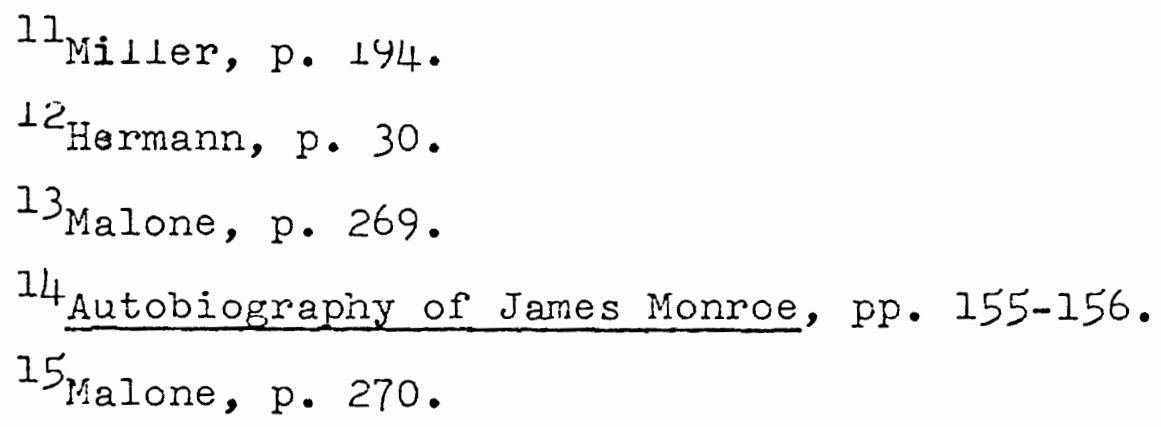


Jefferson, aware of Monroe's financial concerns but sensitive to public criticism, explained in his letter of January 13, 1803 to Monroe that the Republicans' cut in government spending had decreased the amount fornerly given to ministers extraordinary in previous administrations. Jefferson advocated that economy be Monroe's watchword:

Mr. Madison's friendship and mine to you being so well known, the public will have eagle eyes to watch if we grant you any indulgences out of the general rule; ....

Despite the apprehension of failure and rinancial strain, Monroe accepted the ministerial post. In an early March letter from New York, the newly-appointed diplomat revealed to Jefferson his determination to succeed at the negotiations in order to avoid public disappointment and disapproval. ${ }^{17}$ He"wöuld "certainly" labour to obtain the best terms-possible."18. Monroe's response to Jefferson's. . request was:

I accept my appointment with gratitude and enter on its duties with an ardent zeal to accomplish its objects. I derive much satisfaction from a knowledge that I am in the hands of those whose views are sound, are attached to justice, and will view my conduct with candor and liberality, under these circumstances I embark with contidence \& am fearless of the result as it respects myself personally. 19

While publicly Jefferson explained that Monroe's

$$
\begin{aligned}
& 16 \text { Jefferson, pp. 345-346. } \\
& 17_{\text {Monroe, }} \cdot 7 . \\
& 18 \text { Ibid.,p. } 7 . \\
& 19 \text { Ibid., p. } 7 .
\end{aligned}
$$


appointment was meant to calm the anxieties of the West, his other reason for engaging Monroe, although disclaimed by him in his Annual Address to Congress, was his loss of confidence in Livingston!s judgment. Livingston's memorial of August 1802, with its allusions to Franco-American solidarity, had brought protests from London which Washington D. C. sought to amend quickly. His offers to. Joseph Bonaparte were bizarre and hinted of kribery. Even the suggestion that the U. S. secure Iand west of the Mississippi River and above the mouth of the Arkansas River was unappealing to Jefferson, who did not want any territory of the $U$. S. to serve as a buffer between British Canada and French Louisiana. 20

In contrast to Iivingston, Monroe's acumen could be implicitly relied upon and his presence in the U. S. allowed him to be thoroughly instructed before departure. Writing to Dupont de Nemours on February 1, 1803, Jefferson emphasized the importance of Monroe's briefing:

Multiplied conversations with him, and views of the subject taken in all the shapes in which it can present itself, have possessed him with our estimates of everything relating to it, with a minuteness which no written communication to $\mathrm{Mr}$. Livingston could ever have attained.2I

$$
\begin{aligned}
& 20 \text { Peterson, pp. } 757-758 . \\
& { }^{21} \text { Jefferson, pp } 347-348 .
\end{aligned}
$$


Armed with the latest instructions, Monroe would journey to France to preserve peace. Jefferson and Madison were confident of Monroe's ability to arrive at a settlement suitable to the French and calming to the western population. The President and the Secretary of state did not view this as an opportune moment to expand the borders of the United States. Expansion was secondary to the resolution of the immediate problem of the closure of New Orleans and the assurance that a violation of American privileges would not recur.

Monroe sailed from New York in early March. It was not known in Washington until April 19 that on March 1, 1803 the Foreign Secretary of Spain had signed a formal order restoring the right of deposit in New Orleans.....Spanish... Minister Yrujo had encouraged his country to suspend the revocation,- pointing out that American leaders would be compelled to declare war due to the pressure placed upon them by the Federalists, the public and even Republicans. Also, Spain, realizing that a resumption of the European war was likely, thought it best to be free of the problems resulting from the closure of New Orleans. 22

Monroe arrived in Paris on April 12, 1803 and with him came now instructions under wnich both ministers were to negotiate. 23

$$
\begin{aligned}
& 22 \text { Malone, p. } 281 \\
& 23 \text { ASPFR, p. } 529 .
\end{aligned}
$$


The ministers were to try to purchase New Orleans. If the French were unwilling to sell the island, then they were to secure jurisdiction-over some other space large enough for a booming commercial town or acquire privileges of holding real estate for commercial purposes, of providing hospitals and of having consuls or other officials in New Orleans. The absolute minimum was the attainment of sovereignty over a place of deposit. 24

The Floridas were also important. From his personal study of the geograpiny of the Gulf Coast, Thomas Jefferson acknowledged the strategic importance of West Florida. West Florida was more valliable to the U. S. than East Florida although together Madison appraised their value at only one quarter that of the island of New orleans. 25.... Monroe...and ... Livingston were therefore authorized to purchase New Orleans and the Floridas for any amount up to $\$ 10,000,000$ : ' If this offer were rejected, they were to negotiate for the most economical settlement which would insure the rights of navigation and deposit. 26

Throughout the negotiations Monroe and Livingston were to assure French officials that American "sensibility and

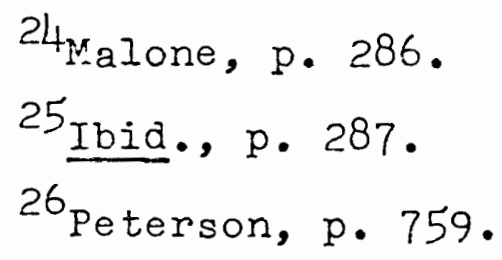


unanimity" demanded that relations with France be precarious until the Mississippi River became the legal boundary between Louisiana and the United states. 27 Therefore, their instructions pertained to lands east of the Mississippi. The only hint that Americans were interested in lands west of the River had come from Iivingston in his previous negotiations with Joseph Bonaparte. His enthusiasm for an American buffer state in the western lands was not shared by Jefferson or Madison. 28

Together Monroe and Livingston were to acquire New Orleans and the Floridas. If both Floridas could not be secured, then West Florida was preferable to East. Conditions favoring their efforts were the instability of the European peace, the possible Anglo-American alliance and the depressed state of French finances. 29 These circumstances did not insure diplomatic success, since one major factor working against their joint commission was Livingstons unfavorable response to Monroe's appointment. In a letter dated January 18, 1803 Madison assured Livingston that Monroe's appointment should not be misconstrued. as a lack of conridence in his diplomatic abilities. Despite this the American minister resented Monroe's nomination. 30

$$
\begin{aligned}
& 27 \text { ASPFR, p. } 540 . \\
& 20_{\text {Malone, p. }} 288 . \\
& 29_{\text {ASPFR, p. } 540 .} \\
& 30_{\text {Ibid., p. } 529 .}
\end{aligned}
$$


To allay Livingston's irdignation and to reenforce Madison's assurances, Jefferson dispatched.a letter to the American minister in early February. Jefferson emphasized the wisdom of Monroe's appointment since it quelled the inflamrnatory attempts of the Federalists and Westerners. The President also explained that Monroe's presence in the U. S. had allowed for an indispensable and thorough briefing which included all ideas and proposals acceptable to the President and Secretary of state. ${ }^{31}$ Such a complete brieing would have been quite difficult, if not impossible, by dispatches between France and the U. S.

The future destinies of our country hang on the event of this negotiation and I am sure that they could not be placed in more able or more zealous hands. On our parts we shall be satisfied that what you do not effect, cannot be effected. Accept therefore assurances of my sincere and constant affection and high respect. 32

Livingston remained nettled by the appointment despite the assurances of "sincere and constant affection and high respect." Nevertheless, upon hearing the news -in March, Livingston sent word to Madison that he would do everything to pave the way for Monroe, whose mission he hoped would be successful. At the same time Livingston informed Madison that Monroe's appointment had not facilitated negotiations but actually impeded them. For one thing, Livingston no longer could

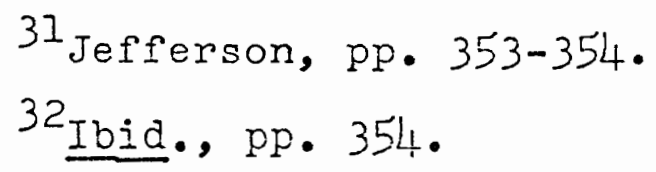


rely on Joseph Bonaparte's assistance. 33 Livingston complained:

It will, however, cut off one resource on which I greatly relied; because I had established a conididence which it will take Mr. Monroe some time to inspire. 34

Livingston's complaint was fabricated since he had just learned of Monroe's appointment and. Joseph Bonaparte had terminated his role as an intermediary between the American minister and the First Consul on January 7, 1803--six days before Congress approved Monroe's nomination! Also impeding negotiations were Pichon's dispatches, which assured the French that Monroe's appointment had tranquilized the West, had hindered negotiations; the French were now willing to wait for Monroe. Not only had negotiations been postponed but seriously undercut since a possible western uprising had been a strong force motivating the French to consider cessions east and west of the Mississippi River. Without that threat, Iivingston concluded, the charees of bringing the French to terms were reduced. 35

Livingston's frustration with the arrested negotiations was compounded by his certainty that prior to the announcement of Monroe's appointment a settiement was about to be negotiated with the French. On March 24, 1803 Livingston informed

$$
\begin{aligned}
& 33 \text { ASPFR, p. } 537 . \\
& 34 \text { Ibid., p. } 338 . \\
& 35_{\text {Dangerfield, pp } 356-357}
\end{aligned}
$$


Madison that a French answer to American requests was ready but had been delayed by the calming news in Pichon's letter. Livingston explained:

He /Talleyrand7. told me that an answer was prepar̄ed, and that everything should be arranged; and I have no doubt the answer contained all those assurances which I have been so long soliciting. 36

When Talleyrand suggested that certain matters be postponed until Monroe!s arrival, Livingston objected:

The United States, sir, have vested me with full powers to receive and make those arrangements; and, in the appointment of Mr. Monroe, jointly with me, as minister extraordinary to the First Consui, it was by no means their intention, considering the variety of accidents which may postpone or prevent his arrival, to defer receiving from the Government of France those explicit confirmations of the treaty of Madrid which must precede every arrangement which it might be thought proper hereafter to enter enter into. 37

Not only was Eivingston concerned with the setback in negotiations but he was anxious lest Americans might incorrectly interpret. Monroe's appointment as evidence of Livingston's neglect of their interests. 38 To remove those suspicions, the American minister suggested the following to Madison:

$$
\begin{aligned}
& 36 \text { ASPFR, p. } 549 . \\
& 37_{\text {Ibid., pp } 550-551 .} \\
& 38_{\text {Ibid., pp. } 548 .}
\end{aligned}
$$


I trust that a communication of my notes to some of them [American citizens] would show that I had gone as far as it was possible for me to go, and perhaps further than my instructions would justify. 39

Although aware that new instructions were coming and despite his assurances to Madison that he would help pave the way foi Monroe, Livingston continued to press French officials in the hopes that he could negotiate a settlement prior to Monroe's arrival. On April 8, 1803 Livingston received a copy of the New York Chronicle which contained the entire text of Senator Ross's Resolution 40 Iivingston, unaware that the Spanish had restored the right of deposit at New Orleans, quickly sent the account to Talleyrand to prove that Monroe's appointment had not completely appeased the west. 41

On April 10 Napoleon issued a surprise statement to his Minister of Finance, Barbé-Marbois, and his Minister of Marine, Denis Decres, which dramatically altered Franco-American negotiations. Fearing that English forces would immediately seize Louisiana if war between France and Britain broke out, Napoleon was considering the cession of all of Louisiana to the United States. 42

${ }^{39}$ ASPFR, p. 548.

lution authorized the President to take New Orleans by force. They were introduced in the Uni ies States Senate in February 1803 but were narrowly defeated. Peterson, p. 758 .

$$
\begin{aligned}
& { }^{4} \text { Dangerfield, p. } 358 . \\
& 42 \text { Ibid., p. } 359 .
\end{aligned}
$$


Marbois in his Histoire de la Louisiane recalled Napoleon's reasoning:

They ask of me only one town in Louisiana; but I already consider the colony as entirely lost; and it appears to me that in the hands of triis growing power it will be more useful to the policy and even to the commerce of France than if I should attempt to keep it. 43

On April 11, 1803 Marbois was summoned by the First Consul and informed that Louisiana would definitely be ceded to the U. S. Napoleon then instructed Marbois:

I direct you to negotiate this attair. Do not even wait for the arrival of Ifr. Monroe: have an interview this very day with Mr. Livingston. 44

Prior to Marbois's meeting with Livingston, the American minister received from Talleyrand an invitation to call at his quarters on the evening of April 11. Upon Livingston's arrival, "the French Minister asked if the United States. would be interestedin purchasing all of Louisiana. 45 Livingston informed Talleyrand that the 'U. S. did not want all of Louisiana but only New Orleans, the Floridas and perhaps a stretch of land west of the Mississippi above the Arkansas River. Talleyrand pointed out that witnout New Orleans, the rest of the territory was almost worthless to France. When pressed to state a purchase price,

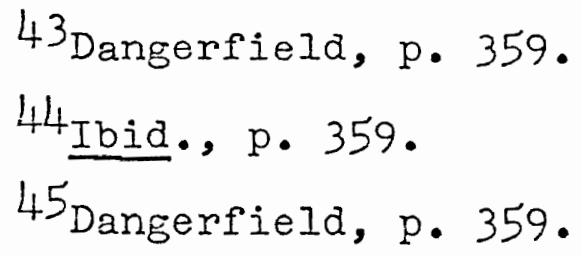


Livingston proposed $\$ 20,000,000$. The French Minister considered this bid too low and encouraged Livingston to reflect on a higher offer before meeting with Marbois on the next day. 46 On April 12 Monroe arrived in Paris. His hopes to become immediately involved in the negotiations were blocked by Livingston's efforts to exclude him. Talleyrand's offer reenforced livingston's thinking that France was quite willine to negotiate. Livingston believed his perseverance and creative diplomacy had paved the way for a settlement with the French and did not want to share that success with Monroe.

Iivingston, despite Talleyrand's offer and his own optimism, in a letter dated April l2th to Monroe insisted that the prospects of the mission were discouraging. The only recourse vas war... Livingston asserted, "War...might do something for us; nothing else would. 147

That evening Monroe met with Livingston, who immediately inquired about the fate of the Ross Resolution. When Monroe informed him of their defeat, Livingston expressed his regret:

With a remark that force only could give us New Orleans and that nothing but the actual possession of thecountry could give sucgess to the mission in which they were associated. 48

At this time Livingston was unaware of Napoleon's sudden statement on April 10 and possibly. believed that his presentation of the Ross Resolution to Talleyrand on April 8

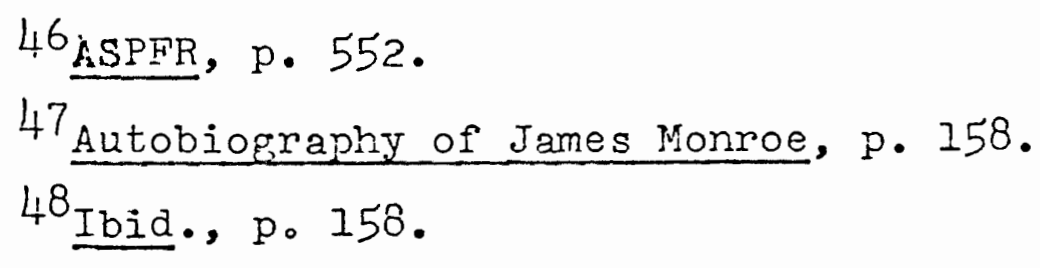


had resulted in the French Minister's offer of the llth to sell all of Louisiana. With the defeat of the Resolution, France, no longer fearing a military advance on New Orleans might withdraw her offer.

Filled with these apprehensions, Livingston kept his April 12 appointment with Marbois. Not wishing to include Monroe in his negotiations with the Minister of France, Livingston advised Monroe that it would be necessary for the new minister to be formally presented to Marbois before entering into any discussions with him. Monroe did not accompany Livingston. 49

At this meeting between Marbois and Livingston, the Minister of Finance informed the American of Napoleon's decision of April loth and his disposition to sell Louisiana. Marbois suggested $\$ 22,500,000$ for the purchase price. Iivingston refused this as exorbitant, explaining that the payment of such a sum woula tnrow the Jefferson administration into disfavor and lead to an election which replaced Republicans with $\checkmark$ those inimical to France. Marbois observed that the opportunity to purchase such an expansive territory was rare and noted that Americans would enjoy the exclusive navigation of the Mississippi and the absence of foreign neighbors. To insure the acquisition of the Floridas, Livingston asked Marbois if France would agree not to possess the Floridas, 
would help the U. S. to procure them, and relinquish all the rights France might have to them. Marbois agreed. In response to another request made by Livingston, Marbois consented to exert his influence and have the negotiations transferred from the Minister of F'oreign Affairs to himself. With all these points agreed upon LIvingston then decided to consult Monroe later about Murbois's asking price. 50

Livingston hirriedly wrote to Madison to inform him that the negotiations had opened even before Mr. Monroe had been presented. 51 Livingston continued:

'l'he field open to us is infinitely larger than our instructions contemplated, the revenue increasing, and the land more than adequate to sink the capital, should we even go the sum proposed by Miarbois.... We shall do all we can to cheapen the purchase; but my 52

Livingston wanted to be given the credit for what he believed was the culmination of his efforts and designs. By discouraging Monroe's attendance at the discussion between Marbois and himself on the pretext that Monroe had not been formally presented, Livingston hoped to exclude the new minister from playing any part in reaching a settlement. George Dangerfield concurs:

And surely it was only a plausible pretext, a point of etiquetie (that Marbois could not treat

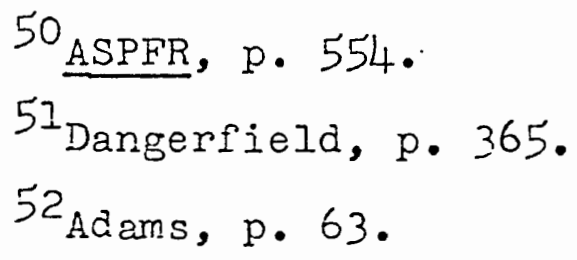


with Monroe until he had been formally presented) too strictly urged, that had kept Monroe away from the conference at the Treasury where the price for Louisiana had first been discussed. 53

Problems between the colleagues had not been resolved by April 15th when Monroe wrote Madison:

I was intormed on my arrival here by Mr. Skipwith that Mr. Livingston mortified at my appointment had done everything in his power to turn the occurences in America, and even my mission to his account, by pressing the Government on every point with a view to show that he had accomplished what was wished without my aid: and perhaps also that my mission had put in hazard what migist otherwise have been easily obtained. His official correspondence will show what occurred prior to my arrival \& sufficiently proves that he did not abstain even on hearing that I was on my way, from the topics intrusted to us jointly....

You will perceive the dilemma into which I have been \& am still placed by this course of proceeding, since I have not only to negotiate with the French Government, especially its ministers, but my colleagues also. 54

On April 14 Monroe's presentation to Marbois took place and he acquired the status of a recognized person. 55 supposedly Monroe and Livingston were to cooperate and through their joint diplomacy secure an agreement favorable to American interests. Although Livingston finally agreed to consult 53 ${ }^{53} D_{\text {angerfield, }}$. 365.

54 Monroe, pp. 9-10.

55 Ammon, p. 210. 
Monroe about Marbois's proposed purchase price, his priae compelled him to complain to Madison that Monroe and he were of unequal rank. Writing to the Secretary of state on April 17, Livingston, protesting his inferior rank and, believing his age and station entitled him not to have anyone placed above him, asserted: "It is important that I should be thought to stand as well with our Government as any other person. "56

The friction between Livingston and Monroe did not prevent negotiations from moving at a rapid pace. Working together they responded to Marbois!s asking price for Iouisiana. Instead of the $\$ 22,550,000$ or $60,000,000$ livres inrbois had suggested, the American diplomats offered 40,000,000 which included American claims totaling 20,000,000 livres. Their proposal was met with protestations of great sorrow by Marbois, who claimed the sum was. insufficient and raised fears that the whole business might be defeated. 57 On April 16th Iivingston called on Marbois again and was informed that the First Consul had received the American ministers' proposition coldly. Napoleon maintained that American claims totaled only 3,000,000 livres, in contrast to Livingston's persistent claim. of 20,000,000. Marbois

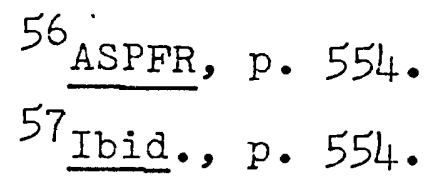


encouraged Livingston to press Talleyrand to make an appointment for him to consult with the First Consul and renew the subject, since Marbois feared that negotiating powers were no longer in his hands. Livingston concluded, "Thus we stand at present, resolving to rest a few days upon our oars."58 Livingston continued to press the debt, all the while complaining to Madison of the insufficiency of the instructions carried to France by Monroe. These instructions gave the commission power to treat for lands only on theeast side of the Mississippi River, while Livingston wanted to include the west side as he had previously done in his attempts to obtain Iana above the Arkansas River. 59

From April 17 to the 27 Monroe was ill and Livingston worked alone. During this time proposals were exchanged with Marbois and with each note their positions drew closer together. By April 24 Napoleon gave Marbois the powers of minister plenipotentiary to treat with the American ministers. On April 27 Marbois carried a projet drawn up by Tallejrand to a meeting at Monroe's lodging where only Monroe, Livingston and Marbois were present. Talleyrand's projet contained the following stipulations: the French Republic was to cede its rights over Louisiana; following the cession the territories and "proper dependencies" of Louisiana were to become a part of the American Union; the U. S. was to favor French commerce

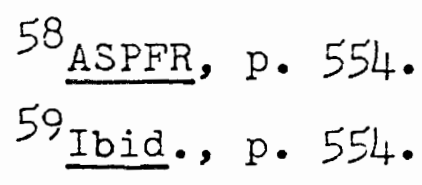


in Louisiana by granting it the same rights American commerce enjoyed with perpetual entrepots established at six points on the Mississippi River and by giving France a perpetual right to navigate the River; the U. S. was to assume all debts due American citizens in accordance with the terms of the Treaty of Morfontaine; and the U.S. was to pay $\$ 20,000,000$ to France. 60

Marbois considered these terms too harsh and proposed another set which he believed acceptable to the First Consul. He suggested $\$ 20,000,000$ for the purchase price, which included $\$ 4,000,000$ in claims (Livingston had appraised them at $\$ 7,500,000)$ as part of the actual cost thereby reducing the net outlay to $\$ 16,000,000$. Livingston was dissatisfied since he believed the claims should be treated in an "especial manner." Despite the First Consul's promises that the claims would be paid and Marbois's assurances that a provision concerning them would be included in the treaty, Livingston continued to press the debt issue. Monroe, fearing the consequences of Livingston's persistence and convinced that if all three of the ministers "were all of the same opinion respecting the debts that the ground on which they stood could not be impaired by the failure of this negotiation," suggested discussing other subjects. 61

$$
\begin{aligned}
& 60 \text { Adams, p. } 66 \\
& 61_{\text {Monroe, pp }} 12-13 .
\end{aligned}
$$


Following this ministerial gathering Livingston and Monroe drew up a compromise projet. On April 29 :: the American ministers went to the Treasury. They proposed paying $\$ 10,000,000$ for Louisiana aliowing $\$ 4,000,000$ for American claims. Only after Monroe and Livingston agreed to raise the offer to $\$ 11,250,000$ for Louisiana and $\$ 3,750,000$ for the liquidation of American claims did Marbois accept. The American ministers' proposal was left with Marbois with the understanding that it would be shown to Napoleon on April 30.62

On May I Monroe was presented to the First Consul and dined witis him. According to Monroe's Journal of Memoranda, no mention was made of Louisiana. 63 At 8:30 p.m. that same day, Livingston and Monroe went to Marbois's house to discuss the treaty. Marbois had no objections to the insertion of the Third Article from the Treaty of San Idlefonso, which Livingston interpreted as including West Florida. 64

62 Dangerfiela, p. 367 . 63 Monroe, pp. 15-16.

64 Dangerfield, p. 368. This Article referred to the extent of the Province of Louisiana in an imprecise way: "...The Colony or Province of Louisiana, with the same extent it now has in the hands of Spain, and that it had when France possessed it; and such as it should be after the treaties subsequently entered into between Spain and other states." Talleyrand believed this Article assured France west Florida and the Mobile Bay region since Iberville appropriated them to Louisiana in 1699! Livingston and Monroe were gratified with Marbois's willingness to include this Article in tre Louisiana Treaty. It was the only provision regarding Louisiana's boundaries and Livingston believed it guaranteed the transfer of West Florida to the U. S. Ammon, p. 213. 
As for commercial privileges, Marbois maintained that all France really sought was an exemption of French productions, manufactures and tonnage from duties not charged Americans and the right to transport these goods into the ports along the Mississippi River. Regarding Arerican Eonds, which the French were willing to accept in payment, Marbois requested that the period during which these Bonds were to be irredeemable be eliminated. Monroe and Livingston objected to that proposal with the argument that some check on the liquidation of the aebt was necessary. The Americans approved an agreement providing for the issuance of Bonds at $6 \%$ interest, which the French could sell on the open market in order to secure the immediate cash desired by Napoleon. Narbois finally aömitted that he recognized the propriety of the check and would take the treaty one last time to receive the First Consul's final approvaz. 65

On Nay 2, 1803 the basic treaty was signed. The claims convention was added on May 9. With the signing of the treaty, Nonroe prepared to leave for Spain but Consul Cambaceres advised waiting and speaking to Marbois first. Marbois was not at home when Morroe called and the American minister decided to pay a visit to the Spanish ambassacior in France, Marquis D'Azara, to discuss with him the subject of the

\section{Monroe, p. 17}


American's journey to Spain to treat for the Floridas. D'Azara said that he hoped the matter could quickiy be resolved. To facilitate the resolution, he had written to the Spanish court two days ago, at the request of Livingston, to inquire whether spain would cede the Florida to the U.S. and to ask authorization for him to treat in France for them. 66

Monroe was surprised to learn of this development, since Livingston had never spoken to him about approaching the Spanish Ambassador and had actually pressed Monroe to travel to Spain. 67

It would appear that Livingston was attempting to have the negotiations brought to France while lionroe was en route to Spain. When Monroe revealed his conversation with the Spanish Ambassador and informed Livingston that his trip to Spain was useless until D'Azara received a response, Livingston defended the conversation as being a casual event in which D'Azara misunderstood some suggestions the American had made. 68 Monroe recorded his response:

I told him that after the arrangement made by our government with respect to Spain, the affair ought to have its course in the train in which it was placed by it: that I could not see any benefit to be derived from an application of the Ambassador to spain to his court in the manner stated by Mr. Livingston, especially if I was to go there. 69

$$
\begin{aligned}
& \text { 66 Monroe, pp. 17-18. } \\
& 67 \text { Ibid., pp. 17-18. } \\
& 68 \text { Ibid., p. } 18 . \\
& 69 \text { Ibid., p. } 19 .
\end{aligned}
$$


The friction between the two American ministers had not vanished. Livingston wanted his pride preserved while Honroe sought tó enhance his political prestige. Apparently the credit for acquiring the Louisiana Purchase could not be shared.

The terms of the treaty were generous and unbelievable considerang the former unwillingness of French officials to negotiate or.even to admit to their possession of Louisiana. Excluding the land west of the Rockies and east of the Mississippi River, 571,873,920 acres were sold to the United States. The Purchase included the present states of Arkansas, Missouri, Iowa, Nebraska, North and South Dakota, parts of Minnesota, Kansas, Colorado, Montana, Wyoming, Louisiana, all of the Indian Territory and part of the Oklahoma Territory. For $\$ 15,000,000$ the U.S. acquired land whose real and personal property value escalated to $\$ 3,190,456,461$ by 1890.70

The purchase amount was payable in 6\% U.S. Government Bonds redeemable at a rate of $\$ 3,000,000$ per year beginning in 1818.71 Napoleon, however, wanted immediate cash and since no French Bank agreed to float such a large bond issue in Europe, the French Government, at the suggestion of the Amerfcan ministers, opened negotiations to sell the bonds in Holland and England through Hope \& Company of Amsterdam

\section{$70_{\text {Hermann, p. } 36 .}$}

${ }^{71}$ Samuel Flagg Bemis, A Short History of American Foreign Policy and Diplomacy (New York: Holt, 1959), p. 65. 
particularly of the third article, the French Republic has an incontestible title to the domain and to the possession of the said Territory: The First Consul of the French Republic desiring to give to the United States a strong proof of his friendship, doth hereby cede to the said United States, in the name of the French Republic, forever and in full sovereignty, the said territory, witn all its rights and appurtenances, as fully and in the same manner as they have been acquired by the French Republic, in virtue of the above-mentioned treaty, concluded with His Catholic Majesty. 74

The second Article included in the cession the adjacent islands belonging to Louisiana--"all public lots and squares vacant lands, and all public buildings, fortifications, barracks, and other edifices, which are not private property." The Third Article required the incorporation of the inhabitants of the ceded territory into the American governmental system as soon as possible. The Fourth established provisions for the transfei of the territory to the U.S. and the Fifth transferred all military posts to American troops. Article Seven formulated arrangements for Spanish and French ships sailing directly from these countries or their colonies and carrying only Spanish or French produce and manufactures to be admitted into the port of New Orleans and all otner legal ports of entry within Louisiana for the next twelve years and to enjoy the same importation privileges granted to U. S. citizens.. Article Eight stipulated that when the twelve 
Jears had expired, French ships would be granted the status given to the "most favored nations in the ports above mentioned. 75

As for the claims convention, Livingston had taken Marbois's projet and attempted to formulate a compromise. When Monroe had read Livingston's proposal, he wrote his colleague on May 5, 1803:

I have examined with great attention the articles of the project which we presented as agreed \& amended between ourselves, to Mr. Marbois \& that which he returned to us, \& find that neither is drawn with sufficient accuracy to accomplish the object which is intended. 76

Nonroe criticized several features of Livingston's proposal, including the absolute submission to the French bureau's decisions in cases-where the claims of American. citizens had been rejected. Monroe rewrote the proposal which was signed by French officials and the American ministers on May $9 a^{77}$

News of the Treaty caused some consternation in England. Rufus King allayed English fears on May 15, 1803 when he assured Lord Hawkesbury that British right to navigate the Mississippi had not been violated. ${ }^{\circ}$ with Anglo-American

$$
\begin{aligned}
& 75 \text { ASPFR, pp. 506-507. } \\
& 76_{\text {Monroe }}, p \cdot 19 . \\
& 77_{\text {Ibid. }}, p \cdot 20 . \\
& 78_{\text {King, }} \text { vol. } 4, p p \cdot 262-263 .
\end{aligned}
$$


relations suffering some strain from impressment and confiscation of goods, King prudently added the following thought in his note to Lord Hawkesbury:

I flatter myself that this communication willl be received with satisfaction, and regarded as a new proof of the disposition of the United States to observe towards His Majesty a spirit of amity and confidence, important at all times, and mure especially, so in present circumstances, to the hamony and mutual prosperity of the two countries.79

On his return to the United States, Rufus King carried with him a letter from Livingston and Monroe which revealed the terms of the treaty. Upon arriving in New York, King dispatched the letter to Madison. On July 3, 1803 Jefferson learned of the treaty and immediately released the news to the National Intelligencer who published it. on July 4.80 The Louisiana Purchase was the result of Napoleon's announcement of April 10 which altered French foreign policy by discarding her dreams of a western empire and extended the borders of the United States hundreds of miles west of the Mississippi River. During 1801 and 1802 France had sacrificed lives and money to secure Santo Domingo from which Louisiana was to be invaded but only succeeded in selling the land, that was to be her new empire, to a

$79_{\text {King, vol. } 4, \mathrm{pp} .262-263 .}$

80 Malone, pp. $284-296$. 
comparatively unimpressive nation. This reversal of French plans and her generous settlement with the U. S. caused Frenchmen and Americans to attempt to discern what factors or persons convinced Napoleon, the author of the French foreign policy, to cede Louisiana.

In his Histoire de la Louisiane Marbois asserted that preliminary discussions were scarcely uruerway and the cession of Iouisiana was unanticipated when Monroe reached Le Havre in early April. ${ }^{81}$ This account strengthens the argument that the French, unsure whether Monroe came beering an "olive branch or a sword" waited to learn his intentions before comitting themselves to Livingston.

In July, after the treaty had become public knowledge, Thomas Jefferson responded to a congratulatory note from General Gates. Publicly impartial, Jefferson wrote:

I find our opposition is very willing to pluck feathers from Monroe, although not fond of sticking them into Livingston's coat. The truth is, both have a just portion of merit; and were it necessary or proper, it would be shown that each has rendered
peculiar services, and of important value. 82

Jefferson acknowledged the merits of both men but Madison criticized Livingston's methods in a letter to Monroe.

${ }^{81}$ Dangerfield, p. 357 .

82 jefferson, p. 402. 
Madison concluded:

It is highly probable that if the appeal to the French Government had been less hackneyed by the ordinary minister, and veen made under the solemnity of a joint and extraordinary embassy, the impression would have been greater and the gain better. 83

Iivingston tried persistently to elevate his role in the successful negotiations. As late as Kay 12, 1803 Livingston was still reporting to Madison that productive negotiations had begun before Monroe's arrival. Iivingston claimed that the Louisiana Purchase was the result of the following: his attempt to obstruct French negotiations for the Floridas by emphasizing their lack of value if New Orleans were not also French; his pressing the payment of the American claims; his dispatching the Ross Resolution to Talleyrand; and his frequent threat to the French of an Anglo-American alliance. 84

Livingston did not just allude to the points of argument he had pressed upon the French, but he attempted to rewrite history. In a letter to Madison dated April 13, 1803 Livingston wrote that Napoleon's decision to sell Lolisiana came on the 10th of April. After sending the letter it occurred to him that people might try to formulate a relationship

${ }^{83}$ Letters and other writines of James Madison (New York: R. Worthington, 1884), vol. 2, p. 184. (Hereafter referred to as Madison.)

$84_{\text {ASPFR, }}$ pp. $557-558$. 
between Monroe's arrival at Le Havre on the 8 th and Bonparte's decision on the loth. Livingston, failing to consider how the French interpreted Monroe's mission, thought this connection could be avoided if Bonaparte made his decision on the morning of April 8 some hours before Monroe's arrival. Therefore, Livingston substituted April 8 for the 10 th in a subsequent letter to Madison and in all of his letters to the United States. In time Livingston's correspondence reached his American friends, all of whom believed that Napoleon had decided to cede Louisiana an April 8, 1803 and Talleyrand had made his offer on the 9 th, not the 1lth. Besides that one letter to Madison dated April 13; the only otner primary source listing the correct dates was Marbois's Histoire and if not for that;" perhaps Livingston's "coup des dates" could have succeeded. 85

To promote the idea of his indispensability, Livingston had printed in the Boston, Washington, Philadelphia and New York newspapers the memorial he had given to French officials in August 1802. At times the publication was accompanied by a laudatory cover letter from some American in Paris. 86 The content of the memorial caused some Federalists to support Livingston when formerly they had called him a "rank Jacobin." They credited him with being primarily responsible for the

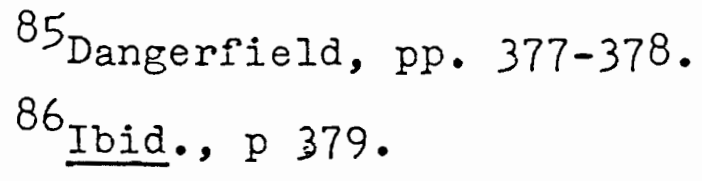


cession since he had acted "without authority from his government." While the Federalists praised Livingston, Madison ascribed the publication to a lack of discretion. 87 To Momroe, Madison wrote on JuIy 30, 1803:

The publication of the: memorial is so improper, and in reference to the writer invites such strico tures, that from him is not to be presumed. The passages against England have not escaped the lash. It would not be very wonderful if they were to be noticed formalfy or informally by the British Legation here. 88

Madison's letter to Iivingston condemning the publication sparked an unrepentent reply. Iivinsston did apologize but only because a poor translation had appeared in the newspapers. He also acknowledged that the "zeal of our friends" forced them to make some extreme statements but these were made only to do him justice. 89

Livingston labored to impress upon American officials and the public his vital role in the Louisiana Purchase. His pride compelled him to continue negotiations after learning of Monroe's appointment and tne new instructions, to stress unceasingly to Madison his successes and to attempt to rewrite history. George Dangerfield decided:

But Livingston was an eclectic: he devoted his life to what he called the culture of laurels. 90

$$
\begin{aligned}
& 87 \text { Maione, p. } 299 . \\
& 88 \text { Madison, p. } 184 . \\
& 89 \text { Dangerfield, p. } 379 . \\
& 90 \text { Ibid:, p. } 299 .
\end{aligned}
$$


In contrast to Livingston, Monroe was self-effacing in his appraisal of the successful negotiations as he ascribed the success to the "wise and firm though moderate measures of the Executive and Congress." 91 He decided:

The decision to offer us the territory by sale was not the effect of any management of mine, for it took place before I reached Paris; nor of my colleague or it would have taken place sooner. 92

Therefore, the success was not actually attributed to his efforts but to the mission, decided upon by the Executive and agreed upon by the senate. These actions demonstrated the purpose and determination of the American government. 93 Other important factors working for the cession were the approaching war between England and France and the possibility of Americans reacquiring the right of deposit by force. 94

Livingston gave himself the credit for a successful settlement with France while Monroe praised Jefferson, Madison and the senate. The central figure in the entire negotiations was really none of these persons or groups but Napoleon Bonaparte himself. The French ministers upheld his wishes and promoted his plans. When Napoleon changed his mind about the western empire, the ministers became less evasive and made offers and

$$
\begin{aligned}
& 91_{\text {Malone, p. } 301 .} \\
& 92 \text { Dangerfield, p. } 379 . \\
& 93 \text { Malone, p. } 301 .
\end{aligned}
$$

94 Autobiography of James Monroe, p. 167. A Short History of American Foreign Policy and Diplomacy. 
concessions to the Americans. Napoleon was the focal personality. His expectation that Great Britain, in the case of war, would capture Louisiana and his conclusion that it would, therefore, be best to cede the land to the U. S. in order to prevent it from becoming British was part of Samuel Bemis's explanation of the First Consul's behavior. AIso Leclerc's defeat and General Victor's inability to leave an icebound harbor destroyed rapoleon's plan for a western empire and made Louisiana worthless to France. 95

Dumas Malone believed Napoleon became willing to seli Louisiana to chech any Anglo-American alliance. Sy leaving Louisiana, France removed the major cause of antagonism between herself and the U. S. and perhaps assured herself of American neutrality. 96

Attributing the sale of Louisiana to a number of causes, George Dangerfield wrote:

No event is due to a single cause: and, unless we dismiss the theory of causation altogether, the cession of Louisiana can be ascribed to a complex of successive or simultareous: pressures.97

Those pressures included the Negroes' resistance at Santo Domingo, Charles IV's and Godoy's unwillingness to release the Floridas to Spain and General Victor's inability

$$
\begin{aligned}
& 95 \text { Bemis, p. } 65 . \\
& 96 \text { Malone, p. } 294 . \\
& 97 \text { Dangerfield, p. } 371 .
\end{aligned}
$$


to leave Holland. The West's reaction to the closure of New Orleans created an additional pressure as Livingston assured Napoleon and Talleyrand that Westerners would take New Orleans by force if they were not guaranteed rights of deposit and navigation. Pichon's dispatches confirmed Livingston's assurances. When Monroe was en route to France, the uncertain mood of his mission created an additional problem as did the Ross Resolution. 98

Dangerfield believes Napoleon lost interest in Louisiana shortly after learning of Leclerc's death and the destruction of his army. These factors, plus General Victor's failure to disembark from hisicebound harbor, led to the disintegration of Napoleon's plans for a western empire. The First Consul's decision to sell Louisiana resulted from these mounting pressures and the "importunate presence of Minister Iivingston." The Americans memorial may have received siight attention from Napoleon when it was first published but D. igerfield proposes that with Napoleon's retentive memory, he would have reconsidered Livingston's question of Louisiana's value to France when his plans in the west appeared to sour. 99

$$
\begin{aligned}
& 98 \text { Dangerfield, p. 370-371. } \\
& 99 \text { Ibid., pp. 370-371. }
\end{aligned}
$$


All of these factors compelied Napoleon to lose interest in Louisiana and to shift his attention to England. Dangerfielà concludes:

It might, therefore, be maintained--and here is maintained--that Bonaparte did not sive up Louisiana because of the imminence of war with England, but that the war with England was due to $h_{i}$ is losing interest in Louisiana.100

War also enters into Merrill Peterson's recitation of "Bonaparte's vagaries." Napoleon, unable to derend Louisiana while marching to the east and fighting England, found he could not march or engage in war with specie. The specie was available through the sale of Louisiana and the destruction of British power was possible by securing the American friendship through the cession of Louisiana to the U. S. 101

Without Napoleon, there would have been no Louisiana Purchase; his approval initiated serious negotiations. The decision to sell almost $600,000,000$ acres became a more attractive alternative as plans for the western empire crumbled. Victory in Santo Domingo required more money and men; the price would be exorbitant and success was not guaranteed.

The loss of Santo Domingo was only one factor in rejecting the plan to attack New Orleans. The bellicose

$$
\begin{aligned}
& 100 \text { Dangerfield, p. } 370 . \\
& 101_{\text {Peterson, pp. } 759-769 .}
\end{aligned}
$$


suggestions of some Americans and Pichon's dispatches led French officials to believe that a sufficient number of U. S. citizens were willing to secure New Orleans by force and to wage war in order to preserve their commercial rights along the Mississippi River. These reactions to the closure of New Orleans, Monroe's appointment and the proposed Ross Resolution testified to America's determination to protect Her interests.

With the west no longer of value to Napoleon, his attention shifted elsewhere. Military aspirations and the depressed state of French finances forced him to seek ways of securing specie. The alternative Livingston had been promoting for months now seemed quite attractive to Napoleon. Livingston's persistence affirmed America's interest in New Orleans and West Florida and encouraged Napoleon. If the U. S. was willing to buy these, perhaps she would pay for all of Louisiana.

Livingston's diplomacy attracted enough attention to be taken seriously by the first Consul. America was intent upon solving a problem which threatened her economy; her persistence could hinder whatever plans France could make for Louisiana without Santo Domingo. American diplomacy did not endear the United. States to Napoleon but rather through it, he foresaw how her willingness to buy land could allow him to pursue French expansionism in Europe. 


\section{CHAPTER VII}

\section{CAVEAT EMPTOR}

The signing of the Louisiana Treaty did not solve all problems but created new concerns and unfavorable reactions in France, Spain and the United States.

Shortly after May 2, 1803, Livingston and Madison heard rumors of Napoleon's dissatisfaction with the treaty. The American ministers informed Madison that Napoleon was said to have regretted signing the Treaty and Talleyrand was making numerous objections in order to discourage the First Consul from honoring the agreement. From various channels Livingston and Monroe learned that the First Counsul considered the Treaty under his control and believed that he could, therefore, impose further conditions until ratifications were exchanged with the United States. ${ }^{1}$ On June 25 Livingston advised Jefferson:

I hope in God that nothing will prevent your immediate ratification...be persuaded that France is sick of this bargain \& that spain is much dissatisfied \& the slightest pretence will lose:you the treaty. 2

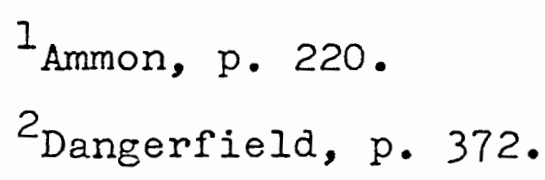


Louisiana had never officially. been surrendered to France under the terms outlined by the Treaty of San IIdefonso. When the Louisiana Treaty became known to Spaniards in Louisiana and Spain, their reaction was unfavorable to the U. S. Public and court opinion forced Minister Yrujo to serve notice on the American Government. The Spanish Minister warned Jefferson and Madison not to submit the treaty for $\checkmark$ ratification since France had contracted with Spain never to cede Louisiana to any other power. By violating that agreement, the treaty cession was void. ${ }^{3}$ There was even the threat that 'Spain would prevent by force America's possession of Louisiana. Madison thought this unlikely and Jefferson, knowing that the Spanish force in the delta numbered only three hundred demoralized men, was inclined to regard it as a bluff. 4

By May 1804 the Spanish opposition had ceased. Yrujo confided to Madison:

The explanations which the Government of France has given to His Catholic Majesty concerning the sale of Louisiana to the U. S., and the amicable disposition on the part of the King my master toward these States, have determined him to abanaon the opposition which, at a prior period, and with the most substantial motives, he haa manifested against that transaction. 5

$$
\begin{aligned}
& 3 \text { Hermann, p. } 34 . \\
& 4 \text { Madison, p. } 316 . \\
& 5 \text { State Papers and Correspondence, p. } 290 .
\end{aligned}
$$


French objections triggered ratification despite Jefferson's qualms about the possible unconstitutionality of the acquisition. The purchase of land, the granting of citizenship to the inhabitants and the division of the territory into states which would be admitted into the Union were not among the enumerated powers given to Congress in the U. S. Constitution nor did they clearly qualify under the "necessary and proper" clause. However, upon learning of Napoleon's discontent, Jefferson abandoned his constitutional apprehensions and concluded:

Whatever Congress shall think it necessary to do, should be done with as little debate as possible, and particularly so far as respects

Some Federalists objected to the Treaty on the basis of its expense, the unintelligible territorial limits of the Purchase and the possible power shift from New England to the South and West when the lands became states.? Despite these objections, ratification soon followed with the U. S. formally acquiring control of New Orleans on December 20, 1803.8

In addition to these reactions and concerns the claims convention in France also experienced some problems primarily resulting from the haste in which they were drawn. The first

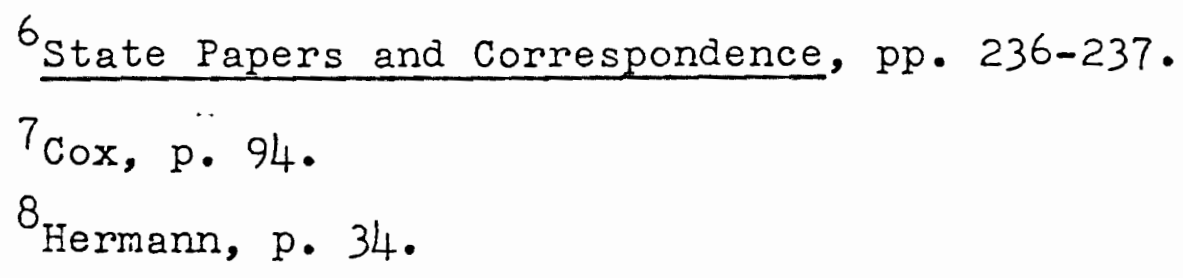


conflict arose when the preamble of the treaty was compared to agreements previously made between the United States and France. The preamble stated that the purpose of the claims convention was to obtain money due American citizens under the Second and Fifth Articles of the Convention of 1800. However, these claims had first been postponed and then abandoned! 9

Secondly, Iivingston's relationship with the claims commission generated controversy and damaged the minister's reputation. This commission consisted of three commissioners who were to approve the claims first. Then the French government and Livingston were to verify them with the latter authorizing the payments. From the beginning Livingston conflicted with the commission whose funds were limited and whose members were unwilling to satisfy the claims Livingston submitted. Disagreement also resulted when the commissioners denied that they labored under Livingston's authority, failed to authorize any claims prior to the United States' ratification of the treaty and insisted that none be paid until all had been examined. The relationship between Livingston and the claims commission became so heated that the commissioners in December 1803 refused to attend a dinner celebrating the treaty since Livingston would be present. 10 
Criticism of Livingston's activities and of his promotion of certain claimants reached Monroe in England who relayed the details to Madison. ${ }^{1}$ Monroe affirmed the integrity of the commissioners and when Livingston appealed to Monroe for cooperation, the American minister in England replied that the commissioners "are responsible for their own conduct, not we..." 12

When the claims commissioners completed their work, they had directed 324 claims to be liquidated, rejected 142 and left five to be decided. The majority of the prize cases were still pending before the Council of Prizes. France conducted the final disposition of the claims and the U. S. Treasury did not make full payment. The payments which were made were tainted with charges of corruption directed toward French bureaus and the reputations of persons involved with the claims, including Iivingston's, were stained. An admirer of Livingston's, Henry Adams, observed, "Livingston's diplomatic career was poisoned by quarrels over this money."13 French and Spanish opposition, the question of the constitutionality of the Purchase and the problems of the claims convention were not the only issues raised by the Louisiana Purchase. There was also the West Florida controversy.

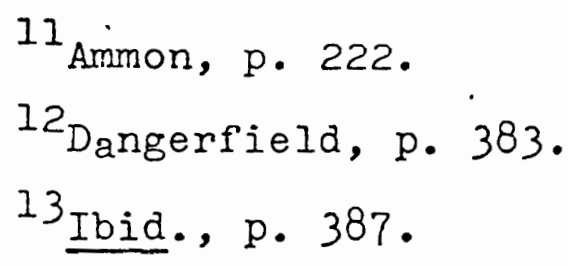


Negotiators in Paris had been instructed to purchase the Floridas as well as New Orleans. The boundaries of the Louisiana Purchase were unclear and therefore the clause stating that Louisiana included all the area which France ceded to Spain in the Treaty of Fontainebleau of 1762 led to multiple interpretations. France remained evasive about the borders while Spain maintained that French boundaries did not extend as far east as the Perdido River. Jefferson agreed with the Spanish until he personally studied the issue in the aftermath of the Purchase and concluded that the boundary was the Perdido River. ${ }^{14}$

In February 1804 Congress enacted the Mobile Act which extended American jurisdiction over the disputed region between the Mississippi and Perdido Rivers. ${ }^{15}$ Spain's protest, her attempts to frustrate Monroe's efforts to secure the Floridas, her refusal to exchange the Floridas for Americanclaimed Texas, and her spoliations on America's neutral shipping estranged the Spanish from Americans and encouraged some U. S. citizens to propose war. Jefferson and his Cabinet hesitated and Monroe failed to acquire the Floridas. 16 The West Florida controversy was not resolved during Jefferson's administrations. In February 1819 spain finally

14 Varg, p. 157 .

15 Cox, p. 89.

${ }^{16}$ Bemis, A Short History of American Foreign Policy and Diplomacy, p. 97 . 
r agreed to cede the Floridas in place of a spoliation paymerst of \$5,000,000 due Americans. 17 These claims resulted from Spain's nonadherence to several terms of the Pinckney Treaty of 1795 . In violation of the treaty Indians residing in Spanish territory had crossed Florida's northern boundary, damaged American property, and murdered approximately 500 Americans over a ten year period of time; the Spanish had arbitrarily closed the mouth of the Mississippi in October 1802; and Spain had failed to observe during the intermittent European wars, American neutrality. 18

Despite America's failure to secure the Floridas during Jefferson's Presidency, foreign affairs appear as a secondary concern in Jefferson's Annual Message of December 1806. The President encouraged internal improvements: the abolition of the slave trade, extensive building of roads and canals, the founding of a national university, fortification of the coasts and the organization of a national militia. 19

17 Sprague, p. 328 .

${ }^{18}$ Samuel Flagg Bemis, John Quincy Adams and the Foundations of American Foreign Policy (New York: Alfred A. Knopf, 1949), pp. 304-305. ${ }^{19}$ Adams, p. 126. 
CHAPTER VIII

\section{CONCLUSION}

$\checkmark \quad$ As a result of the Louisiana Purchase, the United States had almost doubled in size. Louisiana's natural resources and her agricultural products would enhance the American economy while the incorporation of the land as states of the Union would strengthen her position in foreign affairs. After signing the Purchase, Livingston remarked, "We have lived long but this is the noblest work of our whole Iives."I The role of American diplomacy in the acquisition of Louisiana does not deserve the emphasis Iivingston was inclined to give it. Livingston, Jefferson, Madison and Monroe had been persistent in pressing France to relinquish certain areas which if owned by the U. S. would remove the threats to the rights of depositand navigation facing America's western population.

Although these immediate problems were the impetus in negotiating for New orleans and the Floridas, the Louisiana Purchase promised to help fulfill Jefferson's concept of an agrarian America.

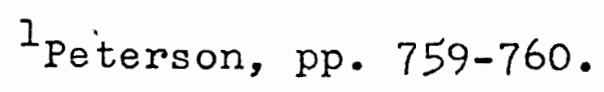


Louisiana's $600,000,000$ acres of land offered innumerable opportunities for farming. According to Jefferson, farming produced the kind of citizen best qualified for meeting the demands of a republican government. 2 The New England Federalists and their menacing policies, which, Jefferson believed, sought to suppress republicanism, would be counterbalanced by the farmers who would soon be cultivating the land secured by the Louisiara Purchase.

To Thomas Jefferson and Napoleon Bonaparte this one transaction furthered American republicanism and French expansionism respectively. Americans were willing to pay for this land at a time when Napoleon needed money and when his aspirations for a French empire in North America were crumbling. Into this realm of Napoleon's faltering dreams and aspiring military conquests in Eurcpe came two American diplomats who offered the French militarist the means to resume French expansionism in Europe and the Mediterranean, and in return received enough land to make the United States the second nation in total area in the world. ${ }^{3}$

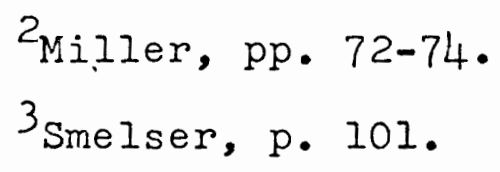




\section{A SELECTED BIBLIOGRAPHY}

Abernethy, Thomas P. The South in the New Nation, 1789-1819.

Vol. 4 of A History of the South, edited by Wendell

Holmes Stephenson and E. Merton Coulter. 10 vols. Louisiana: Louisiana State University Press, 1961.

American State Papers, Foreign Relations. Vol. 2. Washington D. C.: Gales and Seaton, 1832.

Ammon, Harry. James Monroe: The Quest for National Identity. New York: McGraw-Hill, 1971.

Bemis, Samuel Flagg. John Quincy Adams and the Foundations of American Foreign Policy. New York: Alfred A. Knopf, 1949.

$\checkmark$ Bemis, Samuel Flagg. A Short History of American Foreign Policy and Diplomacy. New York: Holt, 1959.

Brown, Stuart Gerry, ed. The Autobiography of James Monroe. Syracuse, New York: Syracuse University Press, 1959.

Chinard, Gilbert. The Letters of Lafayette and Jefferson. Baltimore: Johns Hopkins Press, 1929.

Cobban, Alfred. France Since the Revolution. New York: Barnes \& Noble, 1970 .

Cox, Isaac J. The West Florida Controversy, 1789-1813. Baltimore: John Hopkins Press, 1918.

Cunliffe, Marcus. The Nation Takes Shape, 1789-1837. Chicago: University of Chicago Press, 1959.

Dangerfield, George. Chancellor Robert R. Livingston of New York, 1746-1813. New York: Harcourt, Brace \& Company, 1960.

Darling, Arthur Burr. Our Rising Empire, 1763-1803. New Haven, Connecticut: Yale University Press, 1940.

Donovan, Frank, ed. The Thomas Jefferson Papers. New York: Dodd, Mead \& Company, 1963. 
Hamilton, Stanilaus M., ed. The Writings of James Monroe. Vo1. 4. New York: Knickerbocker Press, 1900.

Hermann, Binger. The Louisiana Purchase. Washington D. C.:

U. S. Government Printing Office, 1898.

Hills, George. Spain. New York: Praeger, 1970.

Hirst, Francis W. Life and Letters of Thomas Jefferson. New York: Macmillan Company, 1926.

Howard, James Q. History of the Louisiana Purchase. Chicago: Callaghan \& Company, 1902.

Inaugural Addresses of the Presidents of the United States from George Washington to John F. Kennedy. Washington D.C.: U. S. Government Printing office, 1961.

King, Charles R., ed. The Life and Correspondence of Rufus King. Vols. 3 and 4. New York: Putnam, 1896.

Koch, Adrienne. Jefferson \& Madison: The Great Collaboration. New York: Oxford University Press, 1950.

Letters and Other Writings of James Madison. Vol. 2. New York: R. Worthington, 1884 .

Lipscomb, Andrew A. and Albert Ellery Bergh, eds. The Writings of Thomas Jefferson. Vol. 10. Washington D.C.: The Thomas Jefferson Memorial Association, 1903.

Malone, Dumas. Jefferson and His Time. Vol. 4, Jefferson the President. Boston: Little, Brown \& Company, 1970.

Miller, John C. The Federalist Era, 1789-1801. New York: Harper \& Row, 1960.

Perkins, Bradford. The First Rapprochement: England and the United States. Philadelphia: University of Pennsylvania Press, 1955.

Peterson, Merrill D. Thomas Jefferson \& the New Nation. New York: Oxford University Press, 1970.

Richardson, James D. A Compilation of the Messages and Papers of the Presidents. Vol. I. New York: U. S. Government Printing office, 1896-1899.

Smelser, Marshall. The Democratic Republic, 1801-1815. New York: Harper \& Row, 1968. 
Sprague, Marshall. So Vast, So Beautiful A Land: Louisiana and the Purchase. Boston: Little, 1974 .

State Papers and Correspondence. Document 431. Washington D.C.: U. S. Government Printing office, 1903.

Varg, Paul A. Foreign Policies of the Founding Fathers. vast Lansing, Michigan: Michigan State University Press, 1963.

Washington, Henry. A., ed. The Writings of Thomas Jefferson. Vols. 4 and 5. Philadelphia: J. B. Lippincott, 187I.

watson, J. Steven. The Reign of George III. Oxford: Clarendon Press, 1960 .

Zahniser, Marvin R. Charles Cotesworth Pinckney: Founding Father. Chapel Hill, North Carolina: University of North Carolina Press, 1967. 